\title{
Modeling Correlated Systemic Liquidity and Solvency Risks in a Financial Environment with Incomplete Information
}

Theodore Barnhill Jr. and Liliana Schumacher 


\title{
IMF Working Paper
}

Monetary and Capital Markets

\section{Modeling Correlated Systemic Liquidity and Solvency Risks in a Financial Environment with Incomplete Information}

\author{
Prepared by Theodore Barnhill Jr. and Liliana Schumacher
}

Authorized for distribution by Laura Kodres

November 2011

\begin{abstract}
This paper proposes and demonstrates a methodology for modeling correlated systemic solvency and liquidity risks for a banking system. Using a forward looking simulation of many risk factors applied to detailed balance sheets for a 10 bank stylized United States banking system, we analyze correlated market and credit risk and estimate the probability that multiple banks will fail or experience liquidity runs simultaneously. Significant systemic risk factors are shown to include financial and economic environment regime shifts to stressful conditions, poor initial loan credit quality, loan portfolio sector and regional concentrations, bank creditors' sensitivity to and uncertainties regarding solvency risk, and inadequate capital. Systemic banking system solvency risk is driven by the correlated defaults of many borrowers, other market risks, and inter-bank defaults. Liquidity runs are modeled as a response to elevated solvency risk and uncertainties and are shown to increase correlated bank failures. Potential bank funding outflows and contractions in lending with significant real economic impacts are estimated. Increases in equity capital levels needed to reduce bank solvency and liquidity risk levels to a target confidence level are also estimated to range from 3 percent to 20 percent of assets. For a future environment that replicates the 1987-2006 volatilities and correlations, we find only a small risk of U.S. bank failures focused on thinly capitalized and regionally concentrated smaller banks. For the 2007-2010 financial environment calibration we find substantially elevated solvency and liquidity risks for all banks and the banking system.
\end{abstract}

JEL Classification Numbers:

Keywords: Solvency risk; systemic liquidity; stress tests.

Authors’ E-Mail Addresses: Barnhill@gwu.edu, and LSchumacher@imf.org

This Working Paper should not be reported as representing the views of the IMF. The views expressed in this Working Paper are those of the author(s) and do not necessarily represent those of the IMF or IMF policy. Working Papers describe research in progress by the author(s) and are published to elicit comments and to further debate. 
Abstract

I. Introduction' 4

II. Systemic Liquidity 7

III. Modeling Steps and Data Requirements 9

IV. Model Calibration to the U.S. Financial Environment and the U.S. Banking System......... 13

A. The U.S. Financial and Economic Environment.................................................. 13

B. Modeling Banks' Assets, Liabilities and Income.................................................. 14

C. Modeling Correlated Systemic Liquidity Risk................................................. 18

V. Results. 21

VI. Summary, Conclusions, and Policy Recommendations ..... 24

Tables

1. Selected Liquidity Stress Testing (ST) Frameworks 6

2. U.S. Financial and Economic Calibrations (1987-2006 and 2007-2010)........................... 30

3. Percentage Bank Failure Rates and Percentage Changes in Real Estate .............................. 31

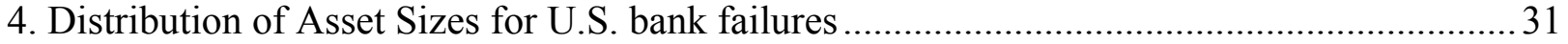

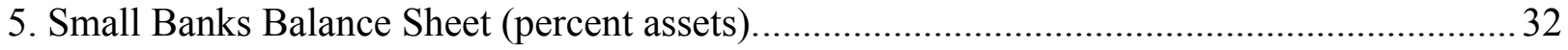

6. Medium Banks Balance Sheet (percent assets). ............................................................... 33

7. Large Banks Balance Sheet (percent assets) ............................................................. 34

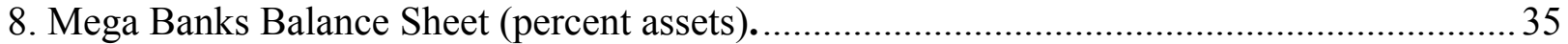

9. Credit Quality of Committed and Outstanding Commercial and Industrial Loans ................36

10. Assumed Distribution of Initial Mortgage Loan to Value Ratios...................................... 36

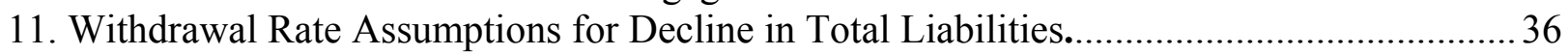

12. Simulated Capital Ratios For Banks using the 1987-2006 Financial Enviroment................ 38

13. Simulated Capital Ratios For Banks using the 2007-2010 Financial Environment Calibration With No Inter-Bank Default Losses. ............................................................. 38

14. Simulated Capital Ratios For Banks using the 2007-2010 Financial Environment Calibration.

15. Correlations Among Incremental Bank Failures Due to Inter-Bank Default losses and Initial

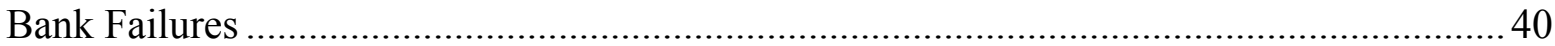

16. Distributional Analysis of Bank Probabilities of Default at T2 as Measured at T1 ............ 41

17. Simulated Distribution of Total Solvency Plus Liquidity Induced Bank Failures .............. 42

18. Probability of Banks Having Liquidity Shortage (Negative Net Cash Flow), 2007-2010 ... 44

19. Simulated Percentage Reduction in Bank Loans after Liquidity Shock ............................. 45

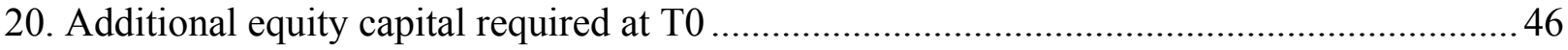

Figures

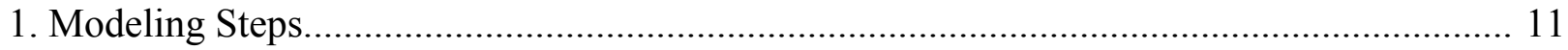

2. Average Corporate Bond Bid-Ask Spread................................................................... 29 
3. Capital Ratios, 1987-2006 and 2007-2010, before Interbank Failures................................. 37

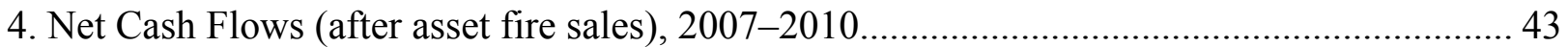

5. Total Loan Reductions..............................................................................................

Appendices

1 Additional information on how the financial environment was simulated...............................2. 27

2. Calibration of asset haircuts in the context of fire sales of assets............................................ 28

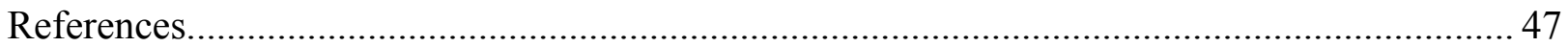




\section{INTRODUCTION ${ }^{1,2}$}

This paper proposes and demonstrates a methodology for modeling correlated systemic solvency and liquidity risks for a banking system. ${ }^{3}$ Correlated financial and economic shocks impact various sectors of an economy and regions of a country in different ways. For example, real estate prices (sector equity returns) may fall much more sharply in some regions (sectors) than others. All entities (individuals, businesses, financial institutions, regulators, and governments, among others) existing at a particular point in time will be impacted simultaneously by adverse financial and economic environment events which may produce correlated defaults by many bank borrowers in various sectors and regions. Correlated recovery rates on loans may also decline in adverse periods. Correlated loan portfolio losses can be expected to produce correlated solvency and potentially liquidity risks for many banks with similar asset and liability structures. In our view most risk assessment methodologies do not adequately model the interaction of the four main drivers of bank solvency risk including financial and economic environment volatility, bank loan sector and region concentration levels, bank loan credit quality, and bank capital levels. The principal contributions of this paper are to model these risk factors in significant detail for 10 banks simultaneously, estimate the probability of banking system systemic solvency and liquidity risks, and evaluate measures that may be adopted in advance to moderate the magnitude of such systemic risks and their potential impacts.

Our view is in line with the literature relating bank runs to extreme episodes of market discipline and with the empirical evidence on the causes of the 2008-2009 global crises. Recent research has made it clear that the global financial crisis has not been a pure liquidity shock but was triggered instead by concerns about the value of bank assets - subprime mortgages and structured products affected by the fall in house prices (e.g., Gorton and Metrick, 2009, and Afonso, Cover, and Schoar, 2010). Our approach is also related to current supervisory approaches for stress testing in which a systemic liquidity shock is triggered by solvency concerns, such as those developed by the Bank of England (Aikman et al., 2009, Wong and Hui, 2009, and van den End and Tabbae, 2009).

Given the interaction between solvency risk and systemic liquidity risk, our framework will jointly model both. Comprehensive macro stress testing is a useful instrument for central banks and supervisors to assess the consequences of severe market disruptions, to understand

\footnotetext{
${ }^{1}$ We wish to thank Laura Kodres, Jeanne Gobat, and the IMF staff for many very helpful comments and suggestions. Ryan Scuzzarella provided excellent research support.

${ }^{2}$ The risk assessments reported in this analysis were undertaken with the ValueCalc Banking System Risk Modeling Software, copyright FinSoft, Inc.

3 The quantitative results presented in this paper are based on publicly available data and are presented for demonstration purposes only.
} 
the different dimensions of systemic risk and estimate the contribution made by different institutions and transactions to potential systemic losses.

The stress tests proposed in this paper were applied to a stylized set of U.S. banks. Using Call Report and other publicly available data, we constructed detailed balance sheets for 10 aggregate banks in four categories: two large banks that aggregate the asset and liabilities of all U.S. banks with assets above $\$ 500$ billion (excluding Morgan Stanley and Goldman Sachs); three large banks that aggregate the assets and liabilities of all U.S. banks with assets between $\$ 100-500$ billion; three medium-size banks that aggregate banks with assets between $\$ 10-100$ billion and two small banks that aggregate banks with assets below 10 billion.

Section II defines systemic liquidity risk. Section III presents the methodology and modeling steps, and data requirements. Section IV calibrates the model for the stylized U.S. banking system. Section V reports the results. Section VI concludes. 
Table 1. Selected Liquidity Stress Testing (ST) Frameworks

\begin{tabular}{|c|c|c|c|c|}
\hline Framework & Bank of England & De Nederlandsche Bank & $\begin{array}{l}\text { Hong Kong Monetary } \\
\text { Authority }\end{array}$ & Proposed ST Framework \\
\hline Data & $\begin{array}{l}\text { Bank by bank financial } \\
\text { reporting }\end{array}$ & $\begin{array}{l}\text { Bank by bank financial } \\
\text { reporting }\end{array}$ & $\begin{array}{l}\text { Bank by bank financial } \\
\text { reporting }\end{array}$ & Bank by bank financial reporting \\
\hline $\begin{array}{l}\text { Origin of } \\
\text { liquidity shocks }\end{array}$ & $\begin{array}{l}\text { Funding liquidity shock (cost } \\
\text { and access) upon downgrade } \\
\text { from solvency shocks (credit } \\
\text { and market losses in macro } \\
\text { ST). }\end{array}$ & $\begin{array}{l}\text { Valuation losses and/or } \\
\text { funding withdrawal to } \\
\text { selected liquidity items. }\end{array}$ & $\begin{array}{l}\text { Deposits are withdrawn in } \\
\text { line with stressed probability } \\
\text { of default (PD) (due to a loss } \\
\text { from asset price declines) of } \\
\text { the bank. }\end{array}$ & $\begin{array}{l}\text { Asset price shocks. Bank } \\
\text { liabilities are withdrawn } \\
\text { following stressed PD of the } \\
\text { bank. }\end{array}$ \\
\hline $\begin{array}{l}\text { Feedback, } \\
\text { spillover, } \\
\text { amplification } \\
\text { effects }\end{array}$ & $\begin{array}{l}\text { Linear, normal time linkages. } \\
\text { Non-linear effects using } \\
\text { subjective but simple scoring } \\
\text { system. Second round effects } \\
\text { through impact on asset price } \\
\text { upon bank deleveraging and } \\
\text { network effects. }\end{array}$ & $\begin{array}{l}\text { Non-linear effects as } \\
\text { banks take deleveraging } \\
\text { actions for larger shocks, } \\
\text { and they feed back to } \\
\text { asset valuation and } \\
\text { funding availability } \\
\text { (second round effects). }\end{array}$ & $\begin{array}{l}\text { Deleveraging to restore lost } \\
\text { funding is costly owing to } \\
\text { distress in asset markets. } \\
\text { Interbank contagion (network } \\
\text { effects). }\end{array}$ & $\begin{array}{l}\text { Banks attempt to restore net } \\
\text { cash flow by selling assets, } \\
\text { which affect on market liquidity } \\
\text { of the assets, further tightening } \\
\text { funding liquidity (through higher } \\
\text { haircuts) }\end{array}$ \\
\hline $\begin{array}{l}\text { Measurement } \\
\text { of stress }\end{array}$ & $\begin{array}{l}\text { Various standard metrics } \\
\text { (solvency ratio, liquidity ratio, } \\
\text { asset value, credit losses, } \\
\text { ratings, profit, etc.). }\end{array}$ & $\begin{array}{l}\text { Distribution of liquidity } \\
\text { buffer across banks and } \\
\text { across severity of shocks. }\end{array}$ & $\begin{array}{l}\text { Probability of cash shortage } \\
\text { and default; expected first } \\
\text { cash shortage time; } \\
\text { expected default time. }\end{array}$ & $\begin{array}{l}\text { Solvency ratio; distributions of } \\
\text { net cash flows and equity; joint } \\
\text { probability of multiple institutions } \\
\text { suffering from simultaneous } \\
\text { cash shortfalls. }\end{array}$ \\
\hline $\begin{array}{l}\text { Origin of } \\
\text { "systemic } \\
\text { liquidity" } \\
\text { characteristics }\end{array}$ & $\begin{array}{l}\text { Initial macroeconomic shocks } \\
\text { and various second round } \\
\text { effects. }\end{array}$ & $\begin{array}{l}\text { From second round } \\
\text { effects. }\end{array}$ & $\begin{array}{l}\text { From initial aggregate shock } \\
\text { on asset prices, network } \\
\text { effects. }\end{array}$ & $\begin{array}{l}\text { Initial aggregate shock on asset } \\
\text { prices and various second } \\
\text { round effects. }\end{array}$ \\
\hline Pros & $\begin{array}{l}\text { Non-linear liquidity shocks } \\
\text { and various second round } \\
\text { effects. }\end{array}$ & $\begin{array}{l}\text { Non-linear second round } \\
\text { effects. }\end{array}$ & $\begin{array}{l}\text { Interaction among credit and } \\
\text { funding and market liquidity } \\
\text { risks. }\end{array}$ & $\begin{array}{l}\text { Non-linear second round } \\
\text { effects, assess joint probability } \\
\text { of liquidity distress, and } \\
\text { contribution of individual bank. }\end{array}$ \\
\hline Cons & $\begin{array}{l}\text { Includes subjective } \\
\text { components to model non- } \\
\text { linearity. }\end{array}$ & $\begin{array}{l}\text { Bank behavioral } \\
\text { assumption and feedback } \\
\text { effect formulated without } \\
\text { strong micro foundation. }\end{array}$ & $\begin{array}{l}\text { No feedback effects from } \\
\text { distress on banks to asset } \\
\text { prices. }\end{array}$ & $\begin{array}{l}\text { Bank behavioral assumption } \\
\text { and feedback effect formulated } \\
\text { without strong micro foundation. }\end{array}$ \\
\hline
\end{tabular}

Note: Bank of England reflects the ST framework proposed by Aikmen and others (2009); De Nederlandsche Bank reflects the ST framework proposed by van den End (2008); and the Hong Kong Monetary Authority reflects the ST framework proposed by Wong and Hui (2009).

Source: Global Financial Stability Report, October 2011 


\section{SYSTEMIC LIQUIDITY}

A systemic liquidity shock is an aggregate shortage of liquidity, i.e. a situation in which many institutions face liquidity shortages simultaneously, as opposed to one institution suffering a liquidity shortage. Systemic liquidity risk is the probability that this situation takes place. A liquidity shortage can manifest as an inability for institutions to roll over funding (funding liquidity risk), the inability to trade assets at normal bid/ask spreads (market liquidity risk), or very frequently, both.

The stress test approach developed in this paper takes the view that absent an aggregate preference shock (i.e. a sudden shift of preferences in favor of higher present consumption) or infrastructure malfunctioning, a systemic liquidity shock - i.e. many institutions suffering a liquidity shortage - is more likely to happen in the presence of a shock to fundamentals that depresses asset values and makes the market reluctant to fund these (suddenly) lower quality assets or the institutions that hold them. ${ }^{4}$ In the presence of incomplete and asymmetric information on the values of assets and the financial condition of banks, this reluctance can also be extended to good assets and solvent institutions. Our approach is consistent with the stress testing literature in which liquidity withdrawals are linked to banks' solvency risk (Table 1).

We propose a stress test of systemic liquidity in which systemic liquidity shocks are modeled as a reaction to shocks to asset values resulting from borrower defaults and other factors. In our approach a liquidity shock (or a "run") is an extreme episode of "market discipline" by which those providing funding (depositors, wholesale investors, and other banks, among others) attempt to sort among ex-ante "good" (solvent) and ex-ante "bad" (insolvent) users of funds in a world of asymmetric information regarding asset values. While the exact timing of a systemic liquidity shock is difficult to forecast, we postulate that they are highly correlated with solvency concerns and contractions in bank lending.

A systemic liquidity shock is closely associated with the notion of bank panics. Traditionally, there have been two leading alternative views to explain the triggers of panics in the more traditional setting of depositors' behavior: the random withdrawals theory and the information-based theory. The random withdrawal approach, as developed in Diamond and Dybvig (1983) postulates that a panic is the realization of a bad equilibrium due to the fulfillment of depositors' self-expectations concerning the behavior of other depositors (a pure liquidity shock). On the other hand, the information-based approach, as reflected in Allen and Gale (1998), claims that a panic is an episode of market discipline during which depositors attempt to sort among ex-ante "good" (solvent) and ex-ante "bad" (insolvent)

\footnotetext{
${ }^{4}$ These triggers explain a large portion of the liquidity shortages experienced during the global crisis and were discussed in the October 2010 GFSR (e.g., need for centralized repo counterparties, better recording of OTC transactions in repositories, and others).
} 
banks in a world of asymmetric information regarding bank asset values. In this context, bank panics can be a normal outcome of business cycles: an economic downturn will reduce the value of bank assets raising the possibility that banks cannot meet their commitments. Gorton (1988) undertook an empirical study to differentiate between the "sunspot" view and the business-cycle view of banking panics. He found evidence consistent with the view that banking panics are related to the business cycle.

There is also consensus that the global financial crisis has not been a pure liquidity shock but was triggered instead by concerns about the value of bank assets-subprime mortgages and structured products affected by the fall in house prices. Gorton and Metrick (2009) characterized the global crisis as system-wide "run" in the securitized banking system-- more precisely a "run on the repo market"-similar to the banking panics of the 19th century. Both episodes, in their view, were triggered by insolvency problems. They find that during 20072008, changes in the LIBOR-OIS spread, a proxy for counterparty risk in the interbank market, was strongly correlated with changes in credit spreads and repo rates for securitized bonds. These changes implied higher uncertainty about bank solvency and lower values for repo collateral. They conclude that the market slowly became aware of the risks associated with the subprime market, which then led to doubts about repo collateral and bank solvency. At some point - August 2007 — a critical mass of such fears led to the first run on repo, with lenders no longer willing to provide short-term finance at historical spreads and haircuts.

Afonso, Cover, and Schoar examined the connections between solvency and liquidity over the global crisis. They test two hypothesis by which shocks to individual banks can lead to market wide reductions in liquidity: (i) an increase in counterparty risk leading to a drying up in liquidity; and (ii) liquidity hoarding, i.e. banks not willing to lend even to high quality counterparties in order to keep liquidity for precautionary reasons. Their findings suggest that concerns about counterparty risks played a much larger role than liquidity hoarding.

Moreover, in the days after Lehman's bankruptcy, loan amounts and spreads became more sensitive to borrower's characteristics: they observe that large borrowers accessed the fed funds market less after Lehman's bankruptcy and from fewer counterparties. Furthermore, it was the worst performing large banks (the "bad" banks) that accessed the market least. They do not observe the complete cessation of lending predicted by some theoretical models that focus on liquidity hoarding.

The October 2008 GFSR showed that systemic (joint) default risk has been the dominant factor in the explanation of interest rate spreads and that systemic (joint) default risk has influenced the spreads since July 2007. It also showed that the repo spread began to presents signs of stress in 2005 when the U.S. housing market began its downturn. It then concluded that broadening access to emergency liquidity alone would not resolve bank funding stresses until broader policy measures, including those aimed at the underlying counterparty credit concerns, were implemented. 
This paper also highlights the importance of relating the policy response to the diagnosis of the shock. Systemic liquidity shocks may all look similar, despite their origin (aggregate liquidity preference shock infrastructure malfunctioning or solvency concerns). However, the different origin is important to inform the policy response, both preemptively, to minimize the probability of a systemic liquidity crisis, and to manage the crisis, once it happens. ${ }^{5}$ For our application to the U.S. banks, we develop a capital surcharge aimed at minimizing the probability that any given bank would experience a destabilizing run. For crisis management, we propose recapitalizing or closing insolvent banks and disclosing enough information to eliminate uncertainties about bank solvency. Liquidity injections by a central bank - that can solve the problem in the case of a change in intertemporal preferences for consumptionwould likely not be effective if there is reluctance to provide funding for suddenly poor quality assets. ${ }^{6}$ Balance between supply and demand of liquidity would only be achieved by deleveraging, restoring asset quality and confidence, and by providing enough information to avoid contagion problems for solvent institutions.

\section{Modeling Steps AND DATA ReQuirements}

Our approach starts with a detailed solvency stress test for multiple banks and then adds, as an innovation, a systemic liquidity component. It can be used to measure correlated systemic solvency and liquidity risk, assess a bank's vulnerability to a liquidity shortfall, and develop a capital surcharge aimed at minimizing the probability that any given bank would experience a destabilizing run.

The ST framework assumes that systemic liquidity stress is caused by rising solvency concerns and uncertainty about asset values. The ST approach models three channels for a systemic liquidity event:

- a stressed macro and financial environment leading to a reduction in funding from the unsecured funding markets due to a heightened perception of counterparty and default risk;

- $\quad$ a fire sale of assets as stressed banks seek to meet their cash flow obligations. Lower asset prices affect asset valuations and margin requirements for all banks in the system, and these in turn affect funding costs, profitability, and generate systemic solvency concerns; and

- $\quad$ lower funding liquidity because increased uncertainty over counterparty risk and lower asset valuations induce banks and investors to hoard liquidity, leading to systemic liquidity shortfalls.

\footnotetext{
${ }^{5}$ An interesting reflection about the policy response to the global crisis and the importance of relating the diagnosis to the policy response can be found in Taylor (2008).

${ }^{6}$ To the extent that a central bank provides liquidity in exchange for a trouble asset, liquidity injections can work because it would allow the bank to deleverage - by getting rid of the trouble asset.
} 
The approach proceeds in four stages as illustrated in Figure 1: (i) modeling the financial and economic environment; (ii) modeling correlated borrower credit risk; (iii) modeling systemic banking system solvency risk; and (iv) modeling correlated systemic liquidity risk. First, thousands of Monte-Carlo simulations are used to simulate correlated changes in many asset prices (foreign exchange rates, interest rates, real estate prices, and market equity indexes), as well as macroeconomic factors that drive bank clients' defaults (equity values, bank clients' leverage) between the current time (T0) and a future time (T1). These simulated prices and macroeconomic factors are used to revalue banks' balance sheets.

A large shock to these prices and macroeconomic factors affect the quality of bank assets directly (higher credit and market risk) and also indirectly through a network of interbank claims. Our model estimates the correlated value of banks' economic capital to asset ratios, the number of bank solvency defaults at $\mathrm{T} 1$, and the probability of future solvency defaults at T2 (as measured at T1).

In simulations with higher bank probabilities of default, bank creditors react by showing reluctance to fund bank assets. Confronted with increasing difficulties to roll over their liabilities, banks need to fire sell assets at distressed prices. This in turn aggravates their economic capital to asset ratios. At the end of the simulation, the model generates a final distribution of economic capital to asset values as well as a distribution of cash flows. Banks are modeled as failing when their capital-to-asset ratios reach a critical threshold value (2 percent) or in the presence of liquidity shortages. Periods with multiple bank failures are likely to also have multiple banks in weakened financial conditions. This is just the time when losses on interbank credit defaults can lead to correlated banking system solvency and liquidity crises. 


\section{Figure 1. Modeling Steps}

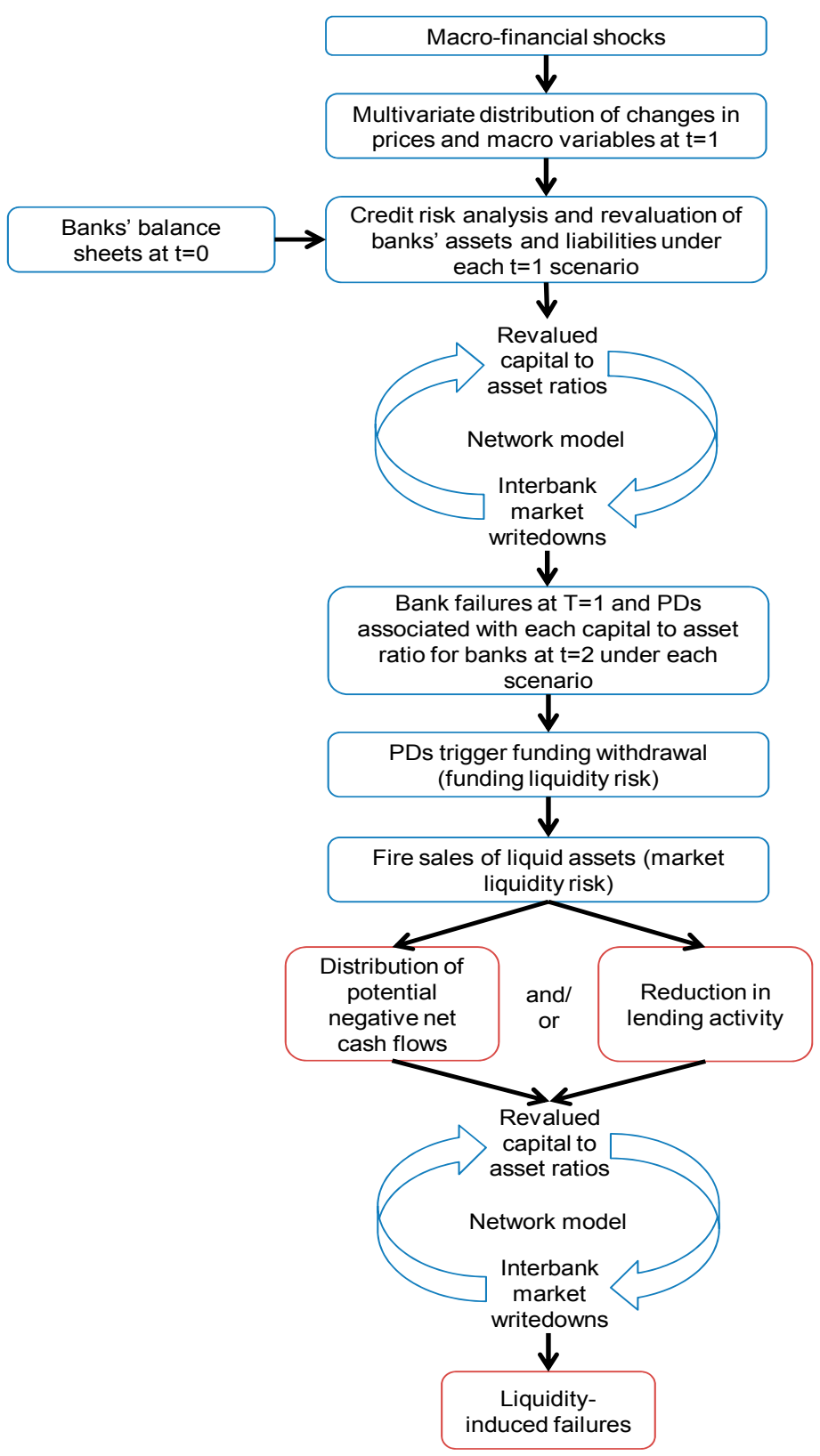

Source: GFSR April 2011 


\section{Data Requirements}

The ST approach has the following intensive data requirements. In some cases, it may be possible to substitute expert opinion for data that may not be available.

- Time series related to the financial and economic environment in which banks operate. These series need to be of sufficient length to allow trends, volatilities, and correlations to be estimated during both "normal" and "stress" periods. The following data are of interest:

- short-term domestic and foreign interest rates and their term structures;

○ interest rate spreads for loans of various credit qualities (securities);

$\bigcirc$ foreign exchange rates (as relevant);

- economic indicators (Gross Domestic Product (GDP), consumer price index; unemployment, and so on);

○ commodity prices (oil, gold, and so on);

- sector equity indices, and

- regional real estate prices.

- Information on banks' assets, liabilities, and, ideally, off-balance-sheet transactions, including hedges, such as:

- various categories of loans, including information about their credit quality, maturity structure, and currencies of denomination;

- currency and maturity structure of the other assets and liabilities;

○ capital as well as operating expenses and tax rates;

- clients' leverage ratios and recovery rates, to be able to calibrate credit risk models, and

○ interbank exposures, including bilateral credit exposures among the various banks.

- Information to enable calibration of behavioral relationships, such as:

○ between banks' default probabilities and a reduction in funding due to bank creditors' concerns about solvency

- between asset fire sales and asset values (including haircuts), which in turn affect liquidity and solvency ratios. 


\section{Model Calibration to the U.S. Financial EnVironment AND The U.S. BANKING SYSTEM}

\section{A. The U.S. Financial and Economic Environment}

For the characterization of the U.S. financial and economic environment we utilize a set of variables including interest rates, interest rate spreads, foreign exchange rates, U.S. economic indicators, global equity indices, 14 S\&P sector equity returns, and 20 Case-Shiller regional real estate price returns. The Financial and Economic Environment Model is calibrated for two different "regimes." The first calibration is based on monthly data from the twenty year period 1987 to 2006 . The second calibration is based on data from the period 2007 to 2010 .

Table 2 gives data on the trends and volatilities of a number of the financial and economic variables used in the risk analysis. Clearly 2007-2010 was a much more adverse period than the previous 20 years. For example average sector equity returns fell from approximately 13 percent to approximately 2 percent per year. Average sector equity return volatility increased from approximately 18 percent per year to 24 percent per year. Average regional real estate price changes fell from approximately 6 percent to -9 percent. It is also important to note the variation in real estate prices by region (e.g., Nevada and Florida suffered much larger real estate price declines). Average regional real estate index volatility increase from approximately 2 percent to 5 percent. The financial environment calibration also included estimations of Hull and White term structure models for domestic and foreign interest rates, volatilities for interest rate spreads, and correlations among the various risk variables.

We view the 2007-2011 banking crises in the United States as having substantial similarities to the one that occurred in Japan during the 1990s. In both cases, the bursting of an asset price bubble resulted in large correlated defaults and losses on bank loans and the failure of many institutions. Table 3 gives a comparison of the percentage changes in real estate prices by $\operatorname{state}^{7}$ (Percent_Change_Real_Estate_Prices) and the percentage failure rates of U.S. banks by state ${ }^{8}$ (Percent_Bank_Failure_Rate) for the period 2007-2011. This data demonstrates that real estate price changes and bank failure rates vary greatly by state and appear to be highly correlated, particularly for large declines in real estate prices (e.g., declines greater than 20 percent). A regression of real estate price changes on bank failure rates finds:

Percent_Bank_Failure_Rate $=-.021-0.387$ Percent_Change_Real_Esate_Prices

T-Stat $-2.74-10.1$

Adjusted R-Square $\quad 0.667$

\footnotetext{
${ }^{7}$ Freddie Mac was the source of historical data on real estate prices by state.

${ }^{8}$ The FDIC was the source of historical data on bank failure rates by state.
} 
This regression supports the proposition that regional real estate prices are an important and statistically significant factor explaining bank failures. We explicitly model regional real estate price changes and how such changes impact banks with more or less concentrated real estate loan portfolios. ${ }^{9}$

Table 4 provides information on the asset size distribution of 342 U.S. bank failures in the January 1, 2007 to February 25, 2011 period as reported by the FDIC. ${ }^{10}$ Some 280 of these failed banks had assets of less than $\$ 1$ billion; an additional 54 banks had assets of between $\$ 1$ and $\$ 10$ billion. However, larger institutions also failed, including six with assets in the $\$ 10$ to $\$ 25$ billion range. Also failing were IndyMac (\$32 billion), Washington Mutual ( $\$ 307$ billion), Lehman Brothers ( $\$ 639$ billion), Wachovia ( $\$ 780$ billion), Freddie Mac ( $\$ 850$ billion of assets, plus approximately $\$ 4$ trillion of guarantees), and Fannie Mae (\$912 billion of assets, plus approximately $\$ 6$ trillion in guarantees). A large majority of the failed banks were smaller in size and we believe regionally oriented with large concentrated positions in real estate loans. However, a number of medium sized and larger institutions having concentrated exposure to real estate price risk also failed in this same period.

\section{B. Modeling Banks' Assets, Liabilities and Income}

Using Call Report Data, ${ }^{11}$ we constructed 10 stylized U.S. banks in four categories as shown in Tables 5-8: Two mega banks that aggregate the asset and liabilities of two groups of banks, with higher and lower equity capital to asset ratios, and assets above $\$ 500$ billion; three large banks that aggregate the assets and liabilities of groups of banks with assets between \$100-500 billion; three medium size banks that aggregate groups of banks with assets between \$10-100 billion and two small banks that aggregate groups of banks with assets below 10 billion. The various banks are sized so that they have an appropriate weighting relative to the overall U.S. banking system. For example, the mega banks have approximately 62 percent of the total assets for the model banking system. A larger or smaller number of banks could be modeled.

Sector and regional concentrations of bank loan portfolios are also a significant risk factor. The smaller banks are modeled as making mortgage loans in one or two states (e.g. California, or Florida and Georgia) and three sectors of the economy (industrial, retail, and services). Medium sized banks are modeled as lending in larger regions (West coast, Mid-

\footnotetext{
${ }^{9}$ Sector concentration is also a significant risk factor for business loan portfolios (see CreditMetrics, 1997). In earlier U.S. banking crises, bank failures were concentrated in so called "energy" or "agriculture" banks, which had concentrated loans positions in particular industries.

${ }^{10}$ In contrast, over the 2000-2006 period the FDIC reports that only 24 U.S. banks failed.

${ }^{11}$ We assumed that the reported balance sheets represent reasonable estimates of current market values for bank assets and liabilities.
} 
America, or East Coast) and four sectors of the economy. Large and mega banks are modeled as lending nationally in 20 regions and 14 sectors of the economy.

Solvency risk in our model depends on bank exposure to borrower creditworthiness (credit risk), including credit concentration, as well as correlated market prices (market risk). The risk assessment horizon was set at one year. The model is flexible to accommodate other risk modeling time steps.

\section{Credit Risk Modeling}

Business and mortgage loan credit risk assessments are based on simulations of business debt to value ratios and property loan to value ratios using a contingent claims type model. ${ }^{12}$ The future values of companies are systematically related to simulated sector equity returns plus a company specific random return. The credit rating of the loans are assumed to change when business debt to value ratios cross-critical boundaries. At identified high debt to value ratios the loans are assumed to default. ${ }^{13}$ In this study we use the U.S. business credit risk model estimated by Barnhill and Maxwell (2002). Correlated variations in recovery rates on business loans are also an important systematic risk factor. In our analysis recovery rates on business loans are modeled as increasing (decreasing) as stock market returns increase (decrease). ${ }^{14}$

Given that we did not have information on the credit quality of corporate borrowers for each bank, we assumed that initially, the set of business loans in U.S. bank portfolios have the same credit quality distribution for all banks and this distribution is the one described in the Shared National Credits Review issued annually by the Board of Governors of the Federal Reserve System, Federal Deposit Insurance Corporation, Office of the Comptroller of the Currency and Office of Thrift Supervision (see Table 9). ${ }^{15}$ Foreign corporate loans are modeled following the same credit risk analysis procedures used for domestic loans. However we do account for foreign exchange rate risk. For those assets and liabilities where credit risk is not modeled, valuation is based on a present value approach where the cash flows are discounted using the simulated interest rates of a selected term structure and the simulated values for the correlated exchange rates, in the case of securities denominated in foreign currency.

\footnotetext{
${ }^{12}$ See Black and Scholes (1973), and Merton (1973).

${ }^{13}$ For a more detailed discussion see Barnhill and Maxwell (2002), Barnhill, Papapanagiotou, and Schumacher (2002), and Barnhill and Souto (2009).

${ }^{14}$ See Cantor, Richard, and Praveen Varma, Moody's (2004).

${ }^{15}$ In the U.S. bank calibration of our model, loans classified as "substandard," "doubtful," and "loss," were modeled as having as a credit risk similar to B, C, and D rated bonds. The balance of the business loan portfolio was divided evenly between the $\mathrm{A}, \mathrm{BBB}$, and $\mathrm{BB}$ rating categories.
} 
Due to lack of an alternative model, loans to individuals were modeled entirely as a portfolio of mortgage loans. This approach has obvious limitations but does capture any correlations among the default rates on other loans to individual and mortgage loans resulting from unemployment rates, and low property prices, among others. The initial loan to value ratios for mortgage loans were estimated from data given in Fannie Mae's and Freddie Mac's annual report plus estimates of the likely distributions of mortgage portfolio loan to value (LTV) ratios based on assumed initial LTV's and trends in national real estate prices (see Table 10).

In our model the future values of properties are systematically related to regional real estate returns plus a property specific random term. The probability of a mortgage loan defaulting is modeled as being related to its LTV ratio. ${ }^{16}$ For LTV's between 1.2 and 1.4, the default rate is set at 20 percent. For LTV's between 1.4 and 1.6, the default rate is set at 40 percent. For LTV's between 1.6 and 1.8, the default rate is set at 60 percent. For LTV's over 1.8 the default rate is set at 80 percent. Recovery rates on mortgage loans are correlated with real estate prices and are assumed to be the value to loan ratio less a 30 percent liquidation cost.

Correlated changes in the values of real estate assets by region and business's by sector are driven by the correlated returns on regional real estate indices and sector equity indices in the financial and economic environment. Correlated default rates on mortgage loans in various regions and business loans in various sectors are driven by the assumed initial loan to value ratios and correlated changes in the values of the real estate and business assets securing the bank loans. Such correlated defaults on bank loan portfolios produce correlated banking system systemic solvency and liquidity risks.

\section{Loan Portfolio Concentration Modeling}

The concentration of bank loans in various sectors (e.g. energy), regions (e.g. Florida), and security types (e.g. mortgage loans) are particularly significant bank risk factors that are often not modeled adequately. To account for loan portfolio concentration risk we model the correlated market and credit risk on 200 business loans distributed across up to 20 sectors of an economy and 200 mortgage loans distributed across up to 20 regions of a country. We find this to be an adequate number of loans, sectors, and regions to statistically distinguish between more concentrated and more diversified portfolios. More sectors, regions, and loans could be modeled. We also model correlated market risk for approximately 100 other bank assets and liabilities.

\footnotetext{
${ }^{16}$ See Bhutta, Dokko, and Shan (2010).
} 


\section{Systemic Solvency Risk Modeling}

One of the outcomes of the risk assessments of the financial and economic environment and bank portfolios after many simulation runs are joint distributions of each of the 10 banks' market value of equity capital at $\mathrm{T} 1$.

$$
M V E_{t}=\sum_{i=1}^{n} A_{i, t}-\sum_{i=1}^{n} L_{i, t},
$$

where $M V E_{t}$ is the simulated market value of the bank's equity at time $\mathrm{t}, \mathrm{A}_{\mathrm{i}, \mathrm{t}}$ is the simulated market value of the $i$ 'th asset at time $t$ which reflects the simulated financial environment variables (e.g., interest rates, exchange rates, equity prices, real estate prices, and etc.) and where appropriate, the simulated credit rating of the borrower, $L_{i, t}$ is the simulated market value of the i'th liability at time $t$ which reflects the simulated financial environment variables (e.g., interest rates, exchange rates, etc.). The bank's asset and liability levels are also adjusted to reflect bank net interest income, fee income plus other income less operating expenses, and taxes over the simulation period. ${ }^{17}$

After many simulation runs joint distributions of the various banks' capital to asset ratios are estimated and used to assess bank defaults and systemic banking system solvency risks at T1.

$$
\text { Capital_Ratio }_{t}=M V E_{t} / \sum_{i=1}^{n} A_{i, t}
$$

For each run of the simulation the simulated capital ratio is also used to estimate each bank's correlated probability of defaulting at T2. These future default probabilities are derived under the assumption that the distribution of changes in capital ratios between T1 and T2 is identical to the distribution of changes in capital ratios between $\mathrm{T} 0$ and $\mathrm{T} 1$.

During times of economic stress, it is likely that default losses on loans will increase, and many banks will either fail or be weakened significantly, particularly if they have similar asset and liability structures. This is just the time when the failure of several banks could, through interbank credit defaults, precipitate a number of simultaneous bank failures. Interbank credit risk is modeled using a network methodology. Since we do not have precise information on inter-bank borrowers/lenders identities, we assumed that the amount of interbank loans made between each bank is proportional to their total inter-bank borrowing and lending.

\footnotetext{
${ }^{17}$ In this study the assumed initial time-step of the simulation (T1) is one-year. This is an important assumption which significantly affects the outcome of the risk assessment. In future work we will explore longer term risk assessments that may offer a mechanism for assessing systemic risks associated with structural changes in economies.
} 
In the current study, and consistent with current U.S. regulations, we model a bank as failing when its ratio of equity capital to assets falls below 2 percent. ${ }^{18}$ In this case, the bank becomes incapable of honoring its interbank obligations and defaults on them. The recovery rate on defaulted interbank obligations is assumed to be 40 percent. Such losses could affect counterparty banks' capital ratios and potentially lead to additional bank failures. A network methodology is applied repeatedly until no additional banks fail, after which the probability of multiple simultaneous bank failures (that is, systemic solvency risk) can be computed. The outcome of this step is again equity to asset ratios and bank failures for T1 - that includes losses due to defaults on interbank claims - and a probability of default for each bank at T2 (estimated as discussed in the previous paragraph) for each run of the simulation.

\section{Modeling Correlated Systemic Liquidity Risk}

A primary contribution of the model to stress testing is the addition of correlated liquidity runs on banks, driven by heightened risks, or uncertainties, regarding future bank solvency. ${ }^{19}$ Changes in bank liabilities observed over the period from 2007 to the first quarter of 2010 were used to develop an estimated relationship between a bank's probability of default and the rate of withdrawal of total liabilities over the period T1 to T2.

Because of incomplete information on particular banks, we assume that bank creditors are also aware of and react to developments in the overall banking system. We thus model system wide weighted average banking system default probabilities and assume that they have some impact on liquidity runs. In particular liquidity runs for a particular bank are modeled as being driven by the probability of failure for that bank at T2 plus a factor equal to ten percent of the system wide weighted average default probability (i.e. the adjusted probability of failure).

Bank liquidity outflows are estimated under two cases. In case 1, total liability withdrawal rates match those experienced by bank holding companies $(\mathrm{BHC})$ with elevated default

\footnotetext{
${ }^{18}$ The FDIC Improvement Act of 1991's Prompt Corrective Action provision states that a bank should be closed when its tangible capitalization reaches 2 percent The trigger point for bank failure could be set in the ST framework model at any relevant regulatory level, including the new leverage ratio as proposed under Basel III.

${ }^{19}$ This approach is in line with current approaches attempting to model bank creditors' behavior in the presence of asymmetric information. For example, for the purpose of calibrating the closure of funding markets in RAMSI, the Bank of England uses an index of default risk called the "danger zone": this index is an equally weighted average of three factors: factors related to solvency, factors related to banks' liquidity position and factors related to confidence. Based on case studies, it is assumed that when the index approaches 35 banks are assumed to default and short-term unsecured markets close to them. Wong and Hui (2008) estimated the relation between bank default risk and the outflow rate of interbank deposits over the Bear Stearns debacle. They found that interbank deposits started to be withdrawn when Bear Stern's default probability reached 8 percent. At 69 percent or higher all interbank deposits were not renewed at maturity. Our approach is closer to the "danger zone" used by RAMSI, but it does not include banks' liquidity position as one of the factors. This exclusion is in line with the assumption made in our model that all banks' projected cash flows are zero, in the absence of a systemic liquidity shock. This is also in line with the empirical evidence that liquidity mismatches per se do not tend to cause systemic liquidity shocks, unless there are also concerns about bank solvency.
} 
probabilities during the 2007-2010 period. ${ }^{20,21}$ In case 2 , at the highest default probabilities withdrawal rates match those experienced by investment banks; since investment banks have a very low level of insured deposits, this case provides a way to calibrate a more stressed scenario where funding sources may dry up very quickly. In case 2 for lower default probabilities we modeled potential reductions in specific liability accounts (e.g., demand deposits, time deposits, jumbo time deposits, Fed Funds, and repos, among others), which reflect actual liability structures of the stylized BHC's. Table 11 summarizes assumptions on total liability withdrawal rates associated with different default probability ranges for each case.

When multiple banks fail, it is highly likely that the risk of future insolvency for the remaining banks is elevated. At the end of each run of the simulation (for example, at T1), future (T2) solvency risks for each bank are computed as previously discussed. These estimated T2 probabilities of default drive assumed bank liquidity flows as shown in Table 11 .

Banks that face a liquidity run are assumed to follow one of two strategies. In the first strategy banks stop lending in the interbank and repo markets, liquidate interest bearing bank deposits, sell government securities, and sell other securities. If these steps do not produce adequate liquidity, they ultimately default on their obligations. ${ }^{22}$ In the second strategy banks sell their liquid securities and reduce their loan portfolios in proportions similar to that observed in U.S. bank holding companies having elevated failure probabilities. ${ }^{23}$

Banks pay a high cost when they are forced to sell assets during periods of extreme financial market stress. We model bank losses resulting from the fire sale of assets. This cost is given by a selling price with an embedded high liquidity premium and consequently well below its fundamental price. Developments in bid-ask spreads in several securities markets during the 2000-09 period $^{24}$ were used as a proxy for fire sale prices. At the peak of the crisis (September 2008), the size of the bid-ask spread was in the 5-10 percent range across different asset qualities, suggesting a discount factor of 3-5 percent to represent the loss suffered by the bank under distress when forced to liquidate assets (see Figure 2).

\footnotetext{
${ }^{20}$ During the crisis, some BHCs were able to increase their access to insured liabilities by converting large uninsured deposits into smaller insured deposits.

${ }^{21}$ These assumptions are based on the analysis of changes in total liabilities for a group of about 700 insured bank holding companies relative to their estimated probability of default.

${ }^{22}$ This case may be illustrative of a very rapidly developing liquidity crisis where banks have little opportunity to adjust their loan portfolios.

${ }^{23}$ This case may be illustrative of banks that face liquidity outflows over time and have an opportunity to adjust their entire asset and liability structure.

${ }^{24}$ Appendix 2 explains how the bid-ask spreads were estimated
} 
These values are in line with Coval and Stafford (2007), Aikman and others (2009), and Duffie and others (2006).

- $\quad$ Coval and Stafford (2007) examine fire sales in equity markets using market prices of mutual fund transactions caused by capital flows from 1980 to 2003 . They find significantly negative abnormal returns in stock prices around widespread forced sales. In a situation where around at least 15 percent of the owners are distressed sellers of the same stock, average abnormal stock return is -10.1 percent for the first quarter, and less than 2 percent for months 4-12.

- Aikman et al (2008), following Duffie et al (2006) conclude that the relation between prices and the magnitude of fire sales is concave and specifically, for asset $\mathrm{j}$ is equivalent to the following expression

$$
P_{j}^{i}=\max \left\{0, P_{j}\left(2-\exp \left(\theta \frac{S_{i j}}{M_{j}+\varepsilon_{j}}\right)\right)\right\}
$$

The price of asset $\mathrm{j}$ following the fire sale, $P_{j}^{i}$, is the maximum of zero and the price before the fire sale, $P_{j}$, multiplied by a discount term. The discount term is a function of value of assets sold by bank $i$ in the fire sale, $S_{i j}$, divided by the depth of the market in normal times $M_{j}$, and scaled by a parameter $\theta$ that reflects frictions, such as search problems, that cause markets to be less than perfectly liquid. Market depth can also be shocked by a term $\varepsilon_{j}$ to capture fluctuations in the depth of markets as macroeconomic conditions vary. For the U.K. banks, they calibrate this relation for the case in which the U.K. bank with the largest holdings of an asset class in its trading portfolio and AFS assets sells all these assets, it generate price falls of 2 percent for equities, 4 percent for corporate debt and 5 percent for mortgage-back securities.

Both liquidity failures of counterparty banks and the fire sale of assets may produce further losses for banks that adversely affect their solvency. Again, these can be modeled with a network methodology applied repeatedly until no additional banks fail. In this way the probability of multiple simultaneous bank failures (that is, correlated systemic solvency and liquidity risk) can be assessed.

The stress test assesses whether banks faced with these withdrawal rates can deleverage in an orderly manner. Initially banks that suffer a run are assumed to stop lending in the interbank market and sell government securities and other liquid assets. Banks may pay a high cost if they are forced to sell potentially less liquid assets, in particular if those assets are associated with a high liquidity premium. In this way, the model captures the interaction between funding and market liquidity and the second round feedback between solvency and liquidity risks. It is important to notice that even if banks can deleverage in an orderly manner, this 
does not eliminate systemic liquidity risks: banks may avoid liquidity failures and potential defaults, but at the expense of lower credit provided to the economy.

\section{Results}

\section{U.S. Systemic Solvency Risk- with no Inter-bank Defaults}

Table 12 below shows the distributional analysis for the simulated equity capital ratios for the stylized 10 bank system using the 1987-2006 financial environment calibration and assuming a one year risk assessment time step. In this analysis potential inter-bank defaults are not modeled. We assume that simulated capital ratios below 0.02 ( 2 percent) result in bank failure. We also show information on the distribution of simultaneous bank failures. We find only a small risk of bank failures focused on thinly capitalized and regionally concentrated smaller banks. We find no likelihood of systemic solvency or systemic liquidity risks. These results are generally consistent with U.S. bank risk in the period prior to 2007.

For the 2007-2010 calibration of the financial and economic environment model, and a one year time step, we find substantially elevated solvency risks for all banks and the banking system. Figure 3 shows the emergence of fatter tails as the mass of the distribution of equity capital ratios (and estimated default probabilities) shifted in a negative direction. Table 13 shows that some of the small more regionally concentrated banks have high failure probabilities. ${ }^{25}$ Eight of the ten banks, including the two mega banks, have a risk of failure in the 0.5 percent range. There is a 1 percent joint probability of four banks failing simultaneously.

The only difference between the analyses presented in Tables 12 and 13 are changes in the trends, volatilities, and correlations of the financial environment variables (e.g., sector equity returns, regional real estate prices, and credit spreads, among others) for the two model calibrations. Thus within our model financial and economic regime shifts to more adverse conditions (as occurred during the 2007-2010 period) is clearly a significant systemic risk factor.

\section{U.S. Systemic Solvency Risk with Inter-bank Defaults}

Adverse financial and economic regime shifts can be expected to cause an increase in correlated defaults on loan portfolios for all banks resulting in the correlated failures of some banks and the weakening of others. When analyzing correlated inter-bank default risk we apply a network methodology repeatedly until no additional banks fail, after which the probability of multiple simultaneous bank failures (i.e., systemic solvency risk) can be computed.

\footnotetext{
${ }^{25}$ This result is consistent with the previously presented overview of the 2007-2011 U.S. banking crises.
} 
Table 14 presents the distributional analysis for the simulated equity capital ratios for the stylized 10 bank system using the 2007-2010 financial environment calibration including potential inter-bank defaults. When potential inter-bank default losses are modeled there is a 1 percent joint probability of six banks failing simultaneously. Thus in our model inter-bank default losses have the potential to significantly increase the number of correlated bank failures (e.g., from four to six at a 1 percent probability).

Table 15 shows an analysis of the correlations among the initial defaults for individual banks and incremental defaults resulting from losses in the inter-bank credit market. As shown in the last row of Table 15 failures by the mega banks have the highest correlations with subsequent bank failures. This occurs in our simulations due to large inter-bank credit losses imposed by the mega banks. Such mega banks can thus be considered to be systemically important.

\section{U.S. Correlated Systemic Solvency and Liquidity Risks}

Our goal is to ultimately model correlated systemic solvency and liquidity risks. As discussed earlier on each run of the simulation we estimate whether each of the ten banks will fail at $\mathrm{T} 1$. We also estimate the probability of each of the remaining solvent banks failing at $\mathrm{T} 2$. We then model correlated liquidity runs as a response to elevated probabilities of bank failure at T2. By design the model is thus structured to estimate correlated solvency and liquidity risks. For example a correlation analysis of simulation results finds a 0.55 correlation between the simulated weighted average probabilities of solvent banks failing at T2 versus the simulated percentage of banking system assets held by banks failing at $\mathrm{T} 1 .^{26}$

Table 16 below gives a distributional analysis on the banks' probabilities of failure at T2 as measured at T1. To these probabilities of default we add a factor equal to 10 percent of the banking system's weighted average probability of default to account for system wide stress impacts. These adjusted default probabilities are used to estimate potential bank liquidity runs as discussed previously. This methodology is simply illustrative of one possible method of accounting for the impact of system wide stress levels on potential bank runs. Clearly more research on how to measure and model these relationships would be useful.

Assuming banks facing a liquidity run do not adjust lending and default if they have a liquidity shortage, Table 17 below shows a distributional analysis for the simulated number of total bank failures resulting from both solvency and liquidity events. This analysis uses the

\footnotetext{
${ }^{26}$ The weighted average probability of solvent banks failing at $\mathrm{T} 2$ is calculated as the sum of the product of the probabilities of each bank failing at T2 times the size of the bank's assets divided by the sum of the assets held by solvent banks.
} 
2007-2010 financial environment calibration. Also as previously discussed and presented in Table 11, we assume two different maximum reductions in total liabilities (i.e. -25 percent and -42 percent). We again apply a network methodology repeatedly until no additional banks fail, after which the probability of multiple simultaneous bank failures (that is, correlated systemic solvency and liquidity risk) can be computed. For the -25 percent maximum reduction in total liabilities, we find a 1 percent joint probability of seven banks failing simultaneously. In this case liquidity failures have the potential to increase the number of correlated bank failures from six to seven. For the -42 percent maximum reduction in total liabilities we find a 1 percent joint probability of eight banks failing simultaneously. In this case liquidity failures have the potential to increase the number of correlated bank failures from six to eight.

The liquidity analysis shows that many banks suffer liquidity shortages in some scenarios (Figure 4). However, the probability of many banks ending the simulation with liquidity shortages is small. In the 2007-10:Q1 financial environment under case 1 (BHC withdrawal rate), Table 18 shows that there is about 2 percent probability that 40 percent of banks will simultaneously find themselves in a situation in which they cannot make due payments. Under the remaining scenarios, banks are able to "shrink," i.e., deleverage in an orderly manner. ${ }^{27}$ In this example, the smaller banks are more affected than the larger ones because of their higher credit risk concentration and exposure to the macro risk factors that triggered the recent crisis. Although many banking failures occurred among smaller banks, their liquidity shortages did not appear to result in a systemic bank funding liquidity crisis. In the 2007-10:Q1 financial environment under case 2 (investment bank withdrawal rate), the probability that one-third of banks suffer a liquidity shortage increases to 12.7 percent.

Such potential liquidity shortages can create pressures for substantial reductions in bank loan portfolios and affect the economy. Indeed, both liquidity shortages and reductions in bank lending were observed during the global crisis. Assuming banks facing a liquidity run follow the second strategy, Table 19 gives a distributional analysis for the simulated percent reduction in total loans as a result of liquidity shocks. Potential liquidity shocks vary significantly by bank depending on the bank's risk characteristics and capital levels. We find a 1 percent probability of an approximately 18 percent reduction in total banks lending. Such liquidity shocks could have significant negative impacts on the real economy. In case 1, if the stylized banks facing liquidity runs reduce both securities and loan portfolios, the impact on total loans would be small (Figure 5, left panel, vertical axis). In case 2, by contrast, a potential liquidity run could lead to a significant reduction in total loans, of up to 43 percent, although with a low probability of less than 1 percent attached to this event (Figure 5, right panel, horizontal axis).

\footnotetext{
${ }^{27}$ In the current study U.S. banks were found to be able to replace a portion of their uninsured liabilities with insured liabilities.
} 
These ST results generally show that the ability of banks to weather a financial and economic shock and its impact on solvency and liquidity depends on a number of factors, including: (i) the size of the shock; (ii) the adequacy of capital; (iii) the availability of liquid assets; and (iv) the exposure to short-term wholesale liabilities (in this model, interbank exposures). In this framework, if institutions were sufficiently capitalized and, hence, able to sell liquid assets, reduce lending, and deleverage in an orderly manner, then there would be no liquidity induced bank failures.

The methodology can be used to estimate an additional required capital surcharge or buffer to reduce the risk of future bank defaults and thus liquidity runs to a given confidence level. In particular using the simulated distribution of bank capital ratios and capital ratio changes, the methodology can estimate the additional capital buffer required at $\mathrm{T} 0$ to reduce to less than 1 percent the probability of a bank experiencing a liquidity run at T1 (Table 20). In our model this is equivalent to reducing the $\mathrm{T} 1$ probability of a bank failing at $\mathrm{T} 2$ to below 10 percent at a 99 percent confidence level. Of the 10 stylized banks, the small banks need to add the most capital because of their higher failure probabilities resulting from undiversified asset exposures to the real estate sector, where credit losses have been the highest. These estimates are based on the risk assessments undertaken with the 2007-2010 financial environment calibration as well as the banks' asset and liability structures. These estimates are derived from the banks' simulated capital ratios at $\mathrm{T} 1$ and the simulated distribution of changes in those capital ratios between $\mathrm{T} 0$ and $\mathrm{T} 1$. We conclude that substantial additional equity capital (e.g., 3 percent to 20 percent of assets) is needed to minimize potential systemic solvency and liquidity risks.

\section{Summary, Conclusions, and Policy Recommendations}

Systemic banking system risks were poorly understood and managed prior to the current crises. We propose and demonstrate a forward looking simulation methodology applied to the financial and economic environment and detailed balance sheets for a 10 bank model banking system. The model estimates the magnitude and probability of correlated solvency and liquidity risks that impact bank borrowers, banks, the banking system, and the real economy.

In our model, banks fail from a solvency perspective when their simulated capital ratios fall below some critical level (e.g., 2 percent). Banks experience liquidity problems when their risk of future insolvency, or the banking system's overall risk of insolvency, rises to an unacceptable level (e.g., 10 percent). Correlated systemic risks materialize when multiple banks become insolvent or face liquidity risks simultaneously. Systemic risks are driven in part by large adverse regime shifts in the financial and economic environment that catch many entities by surprise. Such economic shocks drive down the value of large asset classes (e.g., real estate, and businesses) resulting in dramatically higher default rates and loss rates on loans for many banks simultaneously. Banks experiencing funding outflows are likely to contract lending with significant potential impacts on the real economy. 
In our model, bank solvency and liquidity risks are also driven by asset and liability structures, loan credit quality, sector and regional loan concentrations, and equity capital levels all of which can be changed by bank managers and affected by bank regulators. Such potential systematic risks may only materialize in the context of very adverse financial and economic regime shifts which may only occur infrequently (but have extreme impacts).

Through the inter-bank lending market bank failures may impose additional losses on otherwise solvent banks which cause them to also fail, or increase their probability of failing, thus further increasing systemic risk levels. We find high correlations between insolvencies in mega size banks and incremental insolvencies of other banks throughout the banking system which increases systemic risk.

Insufficient liquid assets that prevent an otherwise orderly "asset shrinking" to offset reductions in funding may also be a significant risk factor. The forced sale of assets at "fire sale" prices may also impact banks' correlated solvency and liquidity risks.

We also find high correlations between banks regarding their (i) solvency failures, (ii) probability of becoming insolvent in the future, (iii) potential liquidity runs, and (iv) potential liquidity shortages and failures.

The model was calibrated with publicly available data on the U.S. financial and economic environment and the U.S. banking system. For the 1987-2006 financial environment calibration, we find only a small risk of bank failures focused on thinly capitalized and regionally concentrated smaller banks. We find no likelihood of systemic solvency or systemic liquidity risks. For the 2007-2010 financial environment calibration, we find substantially elevated solvency and liquidity risks for all banks and the banking system. When potential inter-bank default losses and liquidity run are modeled, 7 of the 10 banks (including one mega bank) fail at the same time with a 1 percent probability.

Within our model we can estimate the current bank equity capital levels that are needed to reduce bank solvency and liquidity risk levels to an agreed target level at a given confidence level. We conclude that substantial additional equity capital (e.g., 3 percent to 20 percent of assets) is needed to minimize potential solvency and liquidity risks. We can also assess the bank and systemic banking system impacts of changes in the other identified risk variables.

We conclude that the public and private sectors need to address correlated systemic solvency and liquidity risks simultaneously. Our model allows policy makers to analyze current risk levels and to identify sets of policy changes to manage these risks before they occur. Important potential policy actions to reduce systemic risk levels include:

- The achievement of reasonably stable economic growth and avoidance of asset price bubbles.

- Limitations on the quantity of high credit risk loans with high loan to value ratios. 
- $\quad$ Managing loan concentration risk in banks and across the banking system.

- More accurate assessments of bank capital requirement levels that account for the interaction between infrequent but severe financial and economic volatility, loan portfolio credit quality, and loan portfolio concentrations.

- $\quad$ Persistent enforcement of bank capital requirements even during extended periods when bank experience low loan portfolio loss rates.

We also suggest that incomplete information may make it impossible for markets to assess the failure risks of institutions and thus potentially produce uninformed runs on otherwise solvent institutions. Deposit insurance schemes likely stabilize the funding for insured institutions. Central banks continue to have an important role to play in providing liquidity to solvent banks facing liquidity pressures. Capital and other risk variables may need to be adjusted for uninsured institutions to reflect their higher liquidity risks.

Our approach highlights the impact of solvency concerns and lack of transparency on the probability of a systemic liquidity run. In turn, this provides strong support to policy responses that try to address the causes of the problem.

Important areas for future research on correlated solvency and liquidity risk include assessing (i) the relationship between system wide stress levels and liquidity risk for individual banks, (ii) correlated changes in all liability accounts for banks with elevated solvency risk, (iii) how volatility in bank loan collateral values increase bank solvency and liquidity risk, (iv) correlations between the volume of repossessed collateral (e.g., real estate) and subsequent price declines for that collateral type and subsequent default rates on related bank loans, and (v) correlated sovereign risk. Modeling potential economic regime shifts is also an exceptionally important risk assessment topic. 


\section{APPENDIX I. ADDITIONAL INFORMATION ON HOW THE FINANCIAL ENVIRONMENT WAS Simulated}

We simulate future financial environments as a set of approximately 50 random variables with trends, volatilities and correlations which are typically estimated from monthly historical data for the country being analyzed. We do not implement any structural models that link asset prices to economic variables such as unemployment or GDP. For further discussion on modeling financial and economic environments see Barnhill, Papapanagiotou, and Schumacher (2002).

We use the Hull and White extended Vasicek model (Hull and White; 1990, 1993, 1994) to model stochastic risk free (e.g., U.S. Treasury) interest rates. Once the risk-free term structure has been estimated then the AA term structure is modeled as a stochastic lognormal spread over risk-free, the A term structure is modeled as a stochastic spread over AA, etc. The mean value of these simulated credit spreads are set approximately equal to the forward rates implied by the initial term structures for various credit qualities (e.g., AA). This procedure insures that all simulated credit spreads are always positive and that the simulated risky term structures are approximately arbitrage free. ${ }^{28}$ In the simulation, the model utilizes the value of the equity market indices and FX rate $(\mathrm{S})$, where it is assumed that $(\mathrm{S})$ follows a geometric Brownian motion where the expected growth rate $(\mathrm{m})$ and volatility $(\sigma)$ are constant (Hull, 2008).

\section{Modeling multiple correlated stochastic variables}

Modeling multiple correlated stochastic variables requires a modification to the methods described above. Hull (1997) describes a procedure for working with an n-variate normal distribution. This procedure requires the specification of correlations between each of the $n$ stochastic variables. Subsequently $\mathrm{n}$ independent random samples $\left(\mathrm{x}_{1} \ldots \mathrm{x}_{\mathrm{n}}\right)$ are drawn from standardized normal distributions. With this information the set of correlated random error terms for the $\mathrm{n}$ stochastic variables can be calculated. For example, for a bivariate normal distribution,

$$
\varepsilon_{1}=\mathrm{x}_{1}
$$$$
\varepsilon_{2}=\rho \mathrm{x}_{1}+\mathrm{x}_{2} \sqrt{1-\rho^{2}}
$$

Where

\footnotetext{
${ }^{28}$ The use of an arbitrage free interest rate model such as the Hull and White extended Vasicek model (Hull and White; 1990, 1993, 1994) allows the estimation of an entire term structure of interest rates at the end of each simulation run that is needed to value financial instruments.
} 
$\mathrm{x}_{1}, \mathrm{x}_{2}=$ independent random samples from standardized normal distributions, $\rho=$ the correlations between the two stochastic variables, and $\varepsilon_{1}, \varepsilon_{2}=$ the required samples from a standardized bivariate normal distribution.

\section{Appendix II. Calibration OF Asset Haircuts in the ConteXt Of Fire Sales of AsSETS}

The impact of the liquidity premium on bank equity is captured by using a haircut based on bid-ask spreads. Bid-ask spreads were calculated in the following way: For corporate bonds, BoA/Merrill Lynch U.S. Corporate indices were downloaded for AAA, AA, A, BBB, BB, B, and $\mathrm{CCC}$ credit ratings. The index members were sorted by issue size, taking the largest 50 issues and then the subsequent 100 largest pre-2006 issues. For these 150 bonds from each index, historical bid and ask prices were downloaded from Bloomberg using the CBBT pricing source. Since the AAA index only has 61 members all bonds were included regardless of size and issue date. (Note: bonds were assumed to have always been in their current credit rating, i.e., no adjustments were made for bonds that might have been rated differently in the past). For government bonds, bid and ask prices for all United States Treasury notes/bonds with amounts outstanding greater than zero were downloaded from Bloomberg.

After downloading the bid and ask data for corporate and government bonds, the difference between the ask and bid is taken to calculate the spread. An arithmetic average is taken across available spreads, ignoring zeros and missing values.

The pricing source is CBBT (Composite Bloomberg Trader). The Composite Bloomberg Bond Trader Price is generated out of all prices at which the security can be traded electronically (executable prices) via the Bloomberg Bond Trader. CBBT requires at least three executable pricing sources with prices and sizes on both sides of the market. Prices must be within the last fifteen minutes for corporate bonds or within five minutes for government and sovereign bonds. A weighted average is calculated for the bid side and the ask side independently. The weighted average is based on the number of sources who price at the second and the third best pricing levels among all the qualified dealers. If there is no current ask/bid price, the previous day price is used. 
Figure 2. Average Corporate Bond Bid-Ask Spread (in basis points)

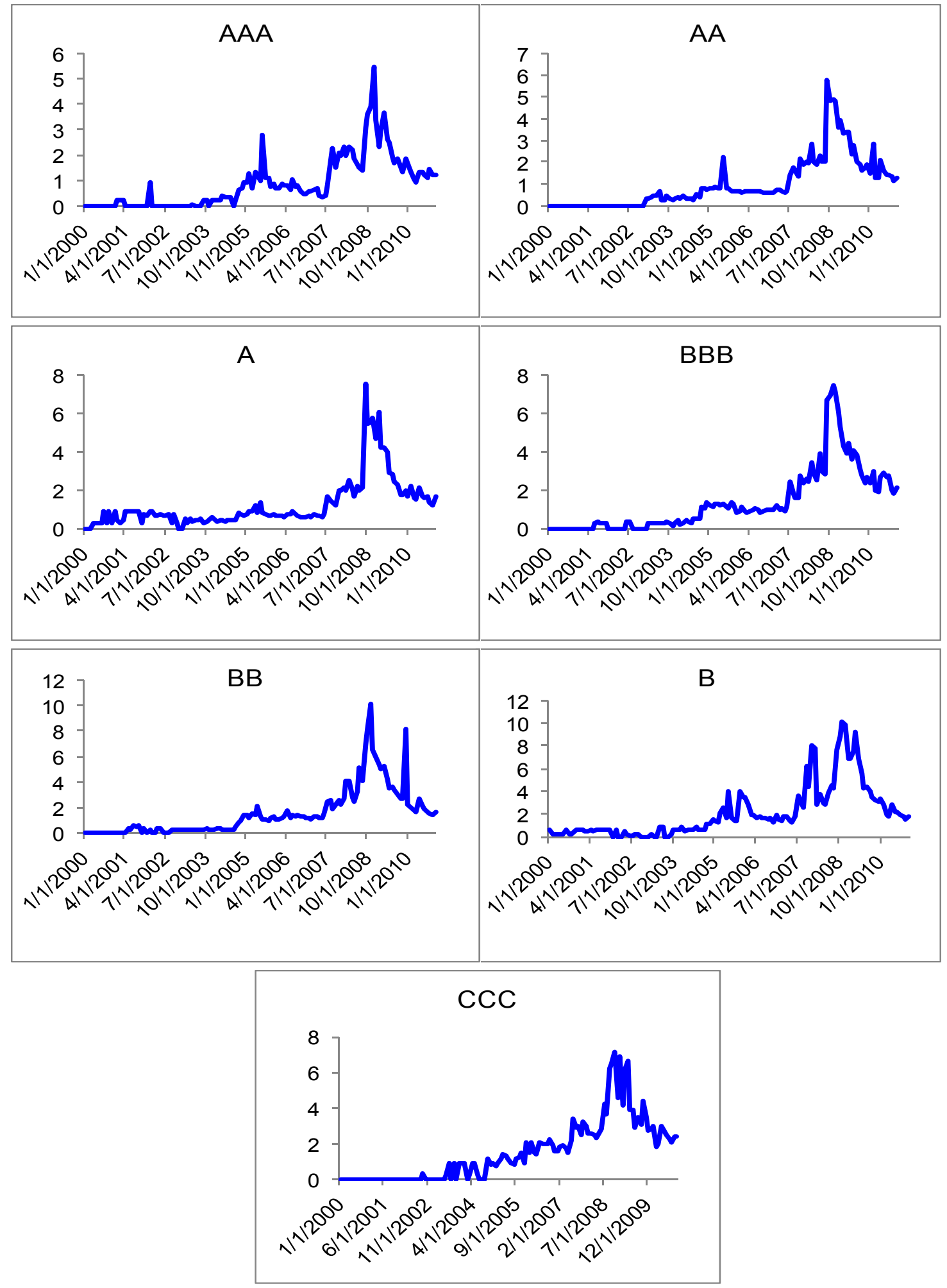

Source: Bloomberg, staff estimates. 
Table 2. U.S. Financial and Economic Calibrations (1987-2006 and 2007-2010)

\begin{tabular}{|c|c|c|c|c|}
\hline Variable & $\begin{array}{c}\text { Trend } \\
\text { 1987-2006 } \\
\text { (Percent } \\
\text { Per Year) }\end{array}$ & $\begin{array}{c}\text { Volatility } \\
1987-2006 \\
\text { (Percent } \\
\text { Per Year) }\end{array}$ & $\begin{array}{c}\text { Trend } \\
2007-2010 \\
\text { (Percent } \\
\text { Per Year) }\end{array}$ & $\begin{array}{c}\text { Volatility } \\
2007-2010 \\
\text { (Percent } \\
\text { Per Year) }\end{array}$ \\
\hline $\begin{array}{ll}\text { Spot Price } 2 \text { (FXRate 9) } & \text { Yen }\end{array}$ & n.a. & 0.094 & n.a. & 0.091 \\
\hline Spot Price 3 (FX Rate 10) Euro & n.a. & 0.083 & n.a. & 0.105 \\
\hline Spot Price 4 (FX Rate 11) Pound & n.a. & 0.083 & n.a. & 0.101 \\
\hline U.S. Industrial Production & 0.029 & 0.018 & -0.014 & 0.034 \\
\hline U.S. Unemployment Rate & -0.020 & 0.087 & 0.204 & 0.106 \\
\hline U.S. CPI & 0.030 & 0.009 & 0.021 & 0.018 \\
\hline MexBol & 0.080 & 0.359 & 0.043 & 0.317 \\
\hline Ibov & 0.149 & 0.500 & 0.181 & 0.403 \\
\hline Cac & 0.074 & 0.189 & -0.082 & 0.288 \\
\hline Dax & 0.085 & 0.220 & 0.014 & 0.307 \\
\hline NKY & -0.028 & 0.251 & -0.061 & 0.209 \\
\hline UKX & 0.069 & 0.147 & -0.076 & 0.235 \\
\hline S\&P Consumer Staples & 0.114 & 0.134 & 0.064 & 0.133 \\
\hline S\&P Consumer Discretionary & 0.113 & 0.169 & 0.023 & 0.252 \\
\hline S\&P Commercial and Professional Services & 0.087 & 0.169 & -0.026 & 0.208 \\
\hline S\&P Energy & 0.171 & 0.187 & 0.044 & 0.241 \\
\hline S\&P Financials & 0.177 & 0.185 & -0.144 & 0.323 \\
\hline S\&P Health Care & 0.137 & 0.147 & 0.020 & 0.168 \\
\hline S\&P Industrials & 0.126 & 0.158 & 0.026 & 0.258 \\
\hline S\&P Information Technology & 0.161 & 0.310 & 0.064 & 0.242 \\
\hline S\&P Materials & 0.105 & 0.193 & 0.066 & 0.276 \\
\hline S\&P Real Estate & 0.165 & 0.127 & 0.016 & 0.367 \\
\hline S\&P Retailing & 0.162 & 0.212 & 0.038 & 0.262 \\
\hline S\&P Telecom & 0.089 & 0.224 & 0.002 & 0.196 \\
\hline S\&P Transportation & 0.113 & 0.181 & 0.084 & 0.237 \\
\hline S\&P Utilities & 0.114 & 0.157 & 0.020 & 0.162 \\
\hline Real Estate AZ-Phoenix & 0.066 & 0.029 & -0.194 & 0.068 \\
\hline Real Estate CA-Los Angeles & 0.076 & 0.036 & -0.117 & 0.055 \\
\hline Real Estate CA-San Diego & 0.074 & 0.034 & -0.102 & 0.055 \\
\hline Real Estate CA-San Francisco & 0.076 & 0.036 & -0.108 & 0.077 \\
\hline Real Estate CO-Denver & 0.050 & 0.019 & -0.018 & 0.042 \\
\hline Real Estate DC-Washington & 0.066 & 0.028 & -0.067 & 0.049 \\
\hline Real Estate FL-Miami & 0.071 & 0.025 & -0.176 & 0.052 \\
\hline Real Estate FL-Tampa & 0.055 & 0.024 & -0.141 & 0.044 \\
\hline Real Estate GA-Atlanta & 0.041 & 0.011 & -0.056 & 0.047 \\
\hline Real Estate IL-Chicago & 0.057 & 0.022 & -0.076 & 0.054 \\
\hline Real Estate MA-Boston & 0.045 & 0.028 & -0.020 & 0.038 \\
\hline Real Estate MI-Detroit & 0.045 & 0.017 & -0.140 & 0.063 \\
\hline Real Estate MN-Minneapolis & 0.055 & 0.019 & -0.079 & 0.079 \\
\hline Real Estate NC-Charlotte & 0.036 & 0.015 & -0.027 & 0.031 \\
\hline Real Estate NV-Las Vegas & 0.063 & 0.035 & -0.226 & 0.054 \\
\hline Real Estate NY-New York & 0.053 & 0.024 & -0.054 & 0.028 \\
\hline Real Estate $\mathrm{OH}$-Cleveland & 0.040 & 0.017 & -0.030 & 0.058 \\
\hline Real Estate OR-Portland & 0.074 & 0.022 & -0.056 & 0.040 \\
\hline Real Estate TX-Dallas & 0.031 & 0.017 & -0.010 & 0.043 \\
\hline Real Estate WA-Seattle & 0.068 & 0.027 & -0.063 & 0.039 \\
\hline Average for 12 Equity Sectors & 0.131 & 0.182 & 0.021 & 0.238 \\
\hline Average for 20 Real Estate Regions & 0.057 & 0.024 & -0.088 & 0.051 \\
\hline
\end{tabular}


Table 3. Percentage Bank Failure Rates and Percentage Changes in Real Estate Prices by State 2007-2011

\begin{tabular}{|c|c|c|c|c|c|}
\hline & $\begin{array}{c}\text { Percentage } \\
\text { of banks in } \\
\text { states failing } \\
\text { between Jan } \\
2007 \text { - Feb }\end{array}$ & $\begin{array}{l}\text { Percentage } \\
\text { change in } \\
\text { home price } \\
\text { index Jun } \\
2007 \text { - Dec }\end{array}$ & & $\begin{array}{c}\text { Percentage } \\
\text { of banks in } \\
\text { states failing } \\
\text { between Jan } \\
2007 \text { - Feb }\end{array}$ & $\begin{array}{l}\text { Percentage } \\
\text { change in } \\
\text { home price } \\
\text { index Jun } \\
2007 \text { - Dec }\end{array}$ \\
\hline State & 2011 & 2010 & State & 2011 & 2010 \\
\hline $\mathrm{NV}$ & 0.244 & -0.543 & PA & 0.017 & -0.083 \\
\hline$A Z$ & 0.175 & -0.517 & VA & 0.017 & -0.208 \\
\hline GA & 0.174 & -0.310 & AR & 0.014 & -0.151 \\
\hline $\mathrm{FL}$ & 0.153 & -0.431 & TX & 0.012 & -0.033 \\
\hline OR & 0.150 & -0.277 & OK & 0.012 & -0.002 \\
\hline WA & 0.144 & -0.257 & SD & 0.011 & 0.018 \\
\hline MO & 0.143 & -0.186 & MS & 0.011 & -0.164 \\
\hline $\mathrm{CA}$ & 0.119 & -0.382 & NE & 0.008 & -0.085 \\
\hline UT & 0.074 & -0.249 & IN & 0.006 & -0.090 \\
\hline MI & 0.069 & -0.285 & LA & 0.006 & -0.074 \\
\hline IL & 0.061 & -0.213 & MA & 0.006 & -0.132 \\
\hline MD & 0.059 & -0.229 & $\mathrm{KY}$ & 0.005 & -0.038 \\
\hline SC & 0.057 & -0.150 & IA & 0.003 & -0.057 \\
\hline NM & 0.056 & -0.136 & AK & 0.000 & -0.033 \\
\hline ID & 0.053 & -0.329 & CT & 0.000 & -0.165 \\
\hline MN & 0.035 & -0.209 & DC & 0.000 & -0.036 \\
\hline $\mathrm{CO}$ & 0.033 & -0.119 & DE & 0.000 & -0.142 \\
\hline NC & 0.027 & -0.131 & $\mathrm{HI}$ & 0.000 & -0.179 \\
\hline WY & 0.026 & -0.082 & ME & 0.000 & -0.112 \\
\hline $\mathrm{AL}$ & 0.025 & -0.141 & MT & 0.000 & -0.114 \\
\hline NJ & 0.024 & -0.166 & ND & 0.000 & 0.053 \\
\hline NY & 0.020 & -0.085 & $\mathrm{NH}$ & 0.000 & -0.173 \\
\hline $\mathrm{KS}$ & 0.020 & -0.053 & RI & 0.000 & -0.208 \\
\hline $\mathrm{OH}$ & 0.020 & -0.149 & $\mathrm{TN}$ & 0.000 & -0.143 \\
\hline \multirow[t]{2}{*}{ WI } & 0.018 & -0.148 & VT & 0.000 & -0.108 \\
\hline & & & WV & 0.000 & -0.031 \\
\hline
\end{tabular}

Sources: FDIC, Freddie Mac.

Table 4. Distribution of Asset Sizes for U.S. bank failures January 2007 to February 2011

\begin{tabular}{lr}
\hline Ranges of Asset Sizes & Frequency \\
\hline Under $\$ 1$ billion & 281 \\
$\$ 1$ to $\$ 5$ Billion & 48 \\
$\$ 5$ to $\$ 10$ Billion & 5 \\
$\$ 10$ to $\$ 50$ Billion & 7 \\
Over $\$ 300$ Billion & 1 \\
Total & $\mathbf{3 4 2}$ \\
\hline
\end{tabular}


Table 5. Small Banks Balance Sheet (percent assets).

\begin{tabular}{|c|c|c|}
\hline & California & Florida-Georgia \\
\hline \multicolumn{3}{|l|}{ ASSETS } \\
\hline $\begin{array}{l}\text { Non Interest Bearing Assets } \\
\text { of which: }\end{array}$ & 2.10 & 2.08 \\
\hline Cash \& Non Int-Bearing Deps & 2.10 & 2.08 \\
\hline Gold & 0.00 & 0.00 \\
\hline Fed Funds Sold & 0.39 & 0.72 \\
\hline Interest Bearing Deposits & 4.32 & 6.19 \\
\hline \multicolumn{2}{|l|}{ of which: } & 17.20 \\
\hline US Govt & 5.63 & 5.00 \\
\hline State \& local & 4.64 & 2.58 \\
\hline MBS (GSE) & 9.38 & 8.31 \\
\hline MBS (Other) & 0.43 & 0.92 \\
\hline ABS & 0.09 & 0.00 \\
\hline Other & 1.15 & 0.35 \\
\hline Repos & 0.02 & 0.04 \\
\hline $\begin{array}{l}\text { Loans } \\
\text { of which: }\end{array}$ & of which: & 68.16 \\
\hline Construction and Development 1-4 family & 1.16 & 1.44 \\
\hline Construction and Development-Other & 4.53 & 6.37 \\
\hline Other Real Estate Loans & 41.50 & 45.16 \\
\hline Non Real Estate Loans & 17.18 & 15.19 \\
\hline Reserves & 1.29 & 1.62 \\
\hline $\begin{array}{l}\text { Investment in Real Estate } \\
\text { of which: }\end{array}$ & 2.24 & 3.16 \\
\hline Premises \& Fixed Assets & 1.57 & 1.95 \\
\hline Total Other Real Estate Owned & 0.67 & 1.21 \\
\hline Invest in Unconsol Subs & 0.08 & 0.08 \\
\hline Intangible Assets & 1.85 & 0.39 \\
\hline Other Assets & 4.49 & 3.55 \\
\hline Adjustment & 0.10 & 0.08 \\
\hline Total Assets & 100.00 & 100.00 \\
\hline \multicolumn{3}{|l|}{ LIABILITIES } \\
\hline Core Deposits & 63.83 & 64.19 \\
\hline Negotiable CDs & 13.42 & 16.34 \\
\hline Fed Funds Purchased & 0.28 & 0.20 \\
\hline Repurchase Agreements & 3.36 & 2.54 \\
\hline Foreign Deposits & 0.54 & 0.33 \\
\hline Other Borrowed Money & 4.64 & 6.62 \\
\hline Subordinated Notes\&Debentures & 0.27 & 0.47 \\
\hline Sub Debt - Trust Pref Sec & 0.85 & 1.68 \\
\hline Trading Liabilities & 0.08 & 0.00 \\
\hline Other Liabilities & 1.39 & 1.02 \\
\hline Equity Capital incl Minority Interest & 11.33 & 6.60 \\
\hline
\end{tabular}

Source: SNL Financial, staff estimates. 
Table 6. Medium Banks Balance Sheet (percent assets).

\begin{tabular}{|c|c|c|c|}
\hline & West Coast & Mid-America & East Coast \\
\hline \multicolumn{4}{|l|}{ ASSETS } \\
\hline $\begin{array}{l}\text { Non Interest Bearing Assets } \\
\text { of which: }\end{array}$ & 1.38 & 1.67 & 2.42 \\
\hline Cash \& Non Int-Bearing Deps & 1.4 & 1.7 & 2.4 \\
\hline Gold & 0.0 & 0.0 & 0.0 \\
\hline Fed Funds Sold & 0.1 & 0.1 & 0.3 \\
\hline Interest Bearing Deposits & 4.4 & 3.1 & 13.6 \\
\hline $\begin{array}{l}\text { Securities } \\
\text { of which: }\end{array}$ & \multicolumn{2}{|c|}{ of which: } & 23.43 \\
\hline US Govt & 4.1 & 2.5 & 8.4 \\
\hline State \& local & 1.3 & 1.8 & 2.0 \\
\hline MBS (GSE) & 12.4 & 12.5 & 8.4 \\
\hline MBS (Other) & 0.4 & 0.8 & 0.2 \\
\hline ABS & 0.1 & 1.2 & 1.0 \\
\hline Other & 0.4 & 0.7 & 2.2 \\
\hline Repos & 0.3 & 0.2 & 1.2 \\
\hline $\begin{array}{l}\text { Loans } \\
\text { of which: }\end{array}$ & 64.92 & 67.72 & 48.87 \\
\hline Construction and Development $1-4$ family & 0.6 & 1.1 & 0.6 \\
\hline Construction and Development-Other & 4.4 & 4.2 & 1.8 \\
\hline Other Real Estate Loans & 42.4 & 34.3 & 28.9 \\
\hline Non Real Estate Loans & 17.4 & 28.2 & 17.5 \\
\hline Reserves & 1.8 & 1.9 & 1.1 \\
\hline $\begin{array}{l}\text { Investment in Real Estate } \\
\text { of which: }\end{array}$ & \multicolumn{2}{|c|}{ of which: } & 1.55 \\
\hline Premises \& Fixed Assets & 1.1 & 1.2 & 1.2 \\
\hline Total Other Real Estate Owned & 0.5 & 0.3 & 0.3 \\
\hline Invest in Unconsol Subs & 0.3 & 0.0 & 0.0 \\
\hline Intangible Assets & 3.5 & 2.8 & 1.3 \\
\hline Other Assets & 5.7 & 5.1 & 9.5 \\
\hline Adjustment & 1.0 & 0.2 & 0.0 \\
\hline Total Assets & 100.00 & 100.00 & 100.00 \\
\hline \multicolumn{4}{|l|}{ LIABILITIES } \\
\hline Core Deposits & 62.7 & 64.6 & 46.9 \\
\hline Negotiable CDs & 8.3 & 7.5 & 6.4 \\
\hline Fed Funds Purchased & 0.3 & 0.8 & 1.6 \\
\hline Repurchase Agreements & 3.6 & 2.9 & 5.1 \\
\hline Foreign Deposits & 1.0 & 1.4 & 13.7 \\
\hline Other Borrowed Money & 7.5 & 8.0 & 12.8 \\
\hline Subordinated Notes\&Debentures & 1.2 & 1.5 & 1.3 \\
\hline Sub Debt - Trust Pref Sec & 0.6 & 0.5 & 0.6 \\
\hline Trading Liabilities & 0.5 & 0.5 & 1.2 \\
\hline Other Liabilities & 1.5 & 1.6 & 1.8 \\
\hline Equity Capital incl Minority Interest & 13.0 & 10.7 & 8.6 \\
\hline
\end{tabular}

Source: SNL Financial, Staff estimates. 
Table 7. Large Banks Balance Sheet (percent assets)

\begin{tabular}{|c|c|c|c|}
\hline & Large 1 & Large 2 & Large 3 \\
\hline \multicolumn{4}{|l|}{ ASSETS } \\
\hline $\begin{array}{l}\text { Non Interest Bearing Assets } \\
\text { of which: }\end{array}$ & 1.34 & 1.26 & 1.63 \\
\hline Cash \& Non Int-Bearing Deps & 1.3 & 1.3 & 1.6 \\
\hline Gold & 0.0 & 0.0 & 0.0 \\
\hline Fed Funds Sold & 0.1 & 0.0 & 0.0 \\
\hline Interest Bearing Deposits & 14.1 & 4.4 & 5.4 \\
\hline Securities & 26.76 & 17.65 & 36.90 \\
\hline \multicolumn{4}{|l|}{ of which: } \\
\hline US Govt & 2.3 & 3.9 & 2.2 \\
\hline State \& local & 0.2 & 1.4 & 2.4 \\
\hline MBS (GSE) & 14.3 & 5.8 & 10.2 \\
\hline MBS (Other) & 3.4 & 3.0 & 2.9 \\
\hline ABS & 2.2 & 1.3 & 8.4 \\
\hline Other & 3.5 & 2.0 & 9.9 \\
\hline Repos & 0.9 & 0.4 & 1.0 \\
\hline \multicolumn{3}{|l|}{ of which: } & 43.61 \\
\hline Construction and Development 1-4 family & 0.5 & 0.3 & 0.3 \\
\hline Construction and Development-Other & 1.2 & 0.7 & 2.1 \\
\hline Other Real Estate Loans & 15.8 & 18.2 & 20.6 \\
\hline Non Real Estate Loans & 25.6 & 42.5 & 20.5 \\
\hline Reserves & 1.7 & 2.1 & 1.0 \\
\hline \multicolumn{3}{|l|}{ of which: } & 1.28 \\
\hline Premises \& Fixed Assets & 1.2 & 0.9 & 1.0 \\
\hline Total Other Real Estate Owned & 0.1 & 0.2 & 0.3 \\
\hline Invest in Unconsol Subs & 0.4 & 1.1 & 0.2 \\
\hline Intangible Assets & 7.6 & 3.0 & 5.4 \\
\hline Other Assets & 6.9 & 11.8 & 6.1 \\
\hline Adjustment & 0.0 & 0.1 & 0.5 \\
\hline Total Assets & 100.00 & 100.00 & 100.00 \\
\hline \multicolumn{4}{|l|}{ LIABILITIES } \\
\hline Core Deposits & 40.4 & 38.5 & 48.7 \\
\hline Negotiable CDs & 7.9 & 3.4 & 4.6 \\
\hline Fed Funds Purchased & 0.1 & 0.1 & 1.2 \\
\hline Repurchase Agreements & 1.1 & 0.7 & 3.1 \\
\hline Foreign Deposits & 13.8 & 1.2 & 14.7 \\
\hline Other Borrowed Money & 10.9 & 31.7 & 10.6 \\
\hline Subordinated Notes\&Debentures & 2.2 & 1.7 & 1.8 \\
\hline Sub Debt - Trust Pref Sec & 1.1 & 1.0 & 0.9 \\
\hline Trading Liabilities & 4.3 & 0.3 & 1.2 \\
\hline Other Liabilities & 5.3 & 9.5 & 2.9 \\
\hline Equity Capital incl Minority Interest & 13.1 & 12.0 & 10.5 \\
\hline
\end{tabular}

Source: SNL Financial, Staff estimates 
Table 8. Mega Banks Balance Sheet (percent assets).

\begin{tabular}{|c|c|c|}
\hline & MEGA E & JKS \\
\hline & Mega 1 & Mega 2 \\
\hline ASSETS & & \\
\hline $\begin{array}{l}\text { Non Interest Bearing Assets } \\
\text { of which: }\end{array}$ & 1.42 & 1.22 \\
\hline Cash \& Non Int-Bearing Deps & 1.4 & 1.2 \\
\hline Gold & 0.0 & 0.0 \\
\hline Fed Funds Sold & 0.0 & 0.0 \\
\hline Interest Bearing Deposits & 4.2 & 4.5 \\
\hline $\begin{array}{l}\text { Securities } \\
\text { of which: }\end{array}$ & 32.61 & 49.85 \\
\hline US Govt & 2.5 & 7.3 \\
\hline State \& local & 1.4 & 1.5 \\
\hline MBS (GSE) & 13.4 & 9.0 \\
\hline MBS (Other) & 3.2 & 4.2 \\
\hline ABS & 1.3 & 1.2 \\
\hline Other & 2.2 & 12.1 \\
\hline Repos & 8.7 & 14.6 \\
\hline $\begin{array}{l}\text { Loans } \\
\text { of which: }\end{array}$ & 50.11 & 34.78 \\
\hline Construction and Development 1-4 family & 0.2 & 0.0 \\
\hline Construction and Development-Other & 1.5 & 0.2 \\
\hline Other Real Estate Loans & 26.6 & 13.5 \\
\hline Non Real Estate Loans & 21.8 & 21.1 \\
\hline Reserves & 1.9 & 1.9 \\
\hline $\begin{array}{l}\text { Investment in Real Estate } \\
\text { of which: }\end{array}$ & 0.93 & 0.56 \\
\hline Premises \& Fixed Assets & 0.7 & 0.4 \\
\hline Total Other Real Estate Owned & 0.3 & 0.1 \\
\hline Invest in Unconsol Subs & 0.6 & 0.8 \\
\hline Intangible Assets & 4.2 & 2.4 \\
\hline Other Assets & 7.6 & 7.2 \\
\hline Adjustment & 0.3 & 0.6 \\
\hline Total Assets & 100.00 & 100.00 \\
\hline LIABILITIES & & \\
\hline Core Deposits & 43.9 & 20.8 \\
\hline Negotiable CDs & 2.9 & 2.4 \\
\hline Fed Funds Purchased & 0.1 & 0.3 \\
\hline Repurchase Agreements & 9.1 & 12.0 \\
\hline Foreign Deposits & 3.7 & 19.3 \\
\hline Other Borrowed Money & 16.8 & 19.9 \\
\hline Subordinated Notes\&Debentures & 2.3 & 1.5 \\
\hline Sub Debt - Trust Pref Sec & 1.3 & 1.0 \\
\hline Trading Liabilities & 4.7 & 7.3 \\
\hline Other Liabilities & 5.3 & 7.3 \\
\hline Equity Capital incl Minority Interest & 10.0 & 8.2 \\
\hline
\end{tabular}

Source: SNL Financial, Staff estimates. 
Table 9. Credit Quality of Committed and Outstanding Commercial and Industrial Loans (In Billions of Dollars per Year)

\begin{tabular}{rrrrrrrrr}
\hline Year & \multicolumn{1}{c}{$\begin{array}{c}\text { Special } \\
\text { Mention }\end{array}$} & \multicolumn{1}{c}{ Standard } & \multicolumn{1}{c}{ Soubtful } & \multicolumn{1}{c}{ Loss } & \multicolumn{1}{c}{ Total } & \multicolumn{1}{c}{ Classified } & \multicolumn{2}{c}{ Total } \\
Criticized & Total \\
Committed & Outstanding \\
\hline 1989 & 24.0 & 18.5 & 3.5 & 0.9 & 22.9 & 46.9 & 692.0 & 245.0 \\
1990 & 43.1 & 50.8 & 5.8 & 1.8 & 58.4 & 101.5 & 769.0 & 321.0 \\
1991 & 49.2 & 65.5 & 10.8 & 3.5 & 79.8 & 129.0 & 806.0 & 361.0 \\
1992 & 50.4 & 56.4 & 12.8 & 3.3 & 72.5 & 122.9 & 798.0 & 357.0 \\
1993 & 31.7 & 50.4 & 6.7 & 3.5 & 60.6 & 92.3 & 806.0 & 332.0 \\
1994 & 31.4 & 31.1 & 2.7 & 2.3 & 36.1 & 67.5 & 893.0 & 298.0 \\
1995 & 18.8 & 25.0 & 1.7 & 1.5 & 28.2 & 47.0 & 1063.0 & 343.0 \\
1996 & 16.8 & 23.1 & 2.6 & 1.4 & 27.1 & 43.9 & 1200.0 & 372.0 \\
1997 & 19.6 & 19.4 & 1.9 & 0.9 & 22.2 & 41.8 & 1435.0 & 423.0 \\
1998 & 22.7 & 17.6 & 3.5 & 0.9 & 22.0 & 44.7 & 1759.0 & 562.0 \\
1999 & 30.8 & 31.0 & 4.9 & 1.5 & 37.4 & 68.2 & 1829.0 & 628.0 \\
2000 & 36.0 & 47.9 & 10.7 & 4.7 & 63.3 & 99.3 & 1951.0 & 705.0 \\
2001 & 75.4 & 87.0 & 22.5 & 8.0 & 117.5 & 192.8 & 2049.0 & 769.0 \\
2002 & 79.0 & 112.0 & 26.1 & 19.1 & 157.1 & 236.1 & 1871.0 & 692.0 \\
2003 & 55.2 & 112.1 & 29.3 & 10.7 & 152.2 & 207.4 & 1644.0 & 600.0 \\
2004 & 32.8 & 55.1 & 12.5 & 6.4 & 74.0 & 106.8 & 1545.0 & 500.0 \\
2005 & 25.9 & 44.2 & 5.6 & 2.7 & 52.5 & 78.3 & 1627.0 & 522.0 \\
2006 & 33.4 & 58.1 & 2.5 & 1.2 & 61.8 & 95.2 & 1874.0 & 626.0 \\
2007 & 42.5 & 69.6 & 1.2 & 0.8 & 71.6 & 114.1 & 2275.0 & 835.0 \\
2008 & 210.4 & 154.9 & 5.5 & 2.6 & 163.1 & 373.4 & 2789.0 & 1208.0 \\
2009 & 195.3 & 337.1 & 56.4 & 53.3 & 446.8 & 642.1 & 2881.0 & 1563.0 \\
2010 & 142.7 & 256.4 & 32.6 & 15.4 & 304.5 & 447.2 & 2519.0 & 1210.0 \\
\hline
\end{tabular}

Note: Sources Shared National Credit Report 2010. Figures may not add to totals due to rounding.

Table 10. Assumed Distribution of Initial Mortgage Loan to Value Ratios

\begin{tabular}{rr}
\hline $\begin{array}{c}\text { Assumed } \\
\text { Initial LTV }\end{array}$ & $\begin{array}{c}\text { Percentage } \\
\text { of Mortgage } \\
\text { Loans }\end{array}$ \\
\hline & \\
0.355 & 0.090 \\
0.710 & 0.110 \\
0.800 & 0.350 \\
0.900 & 0.120 \\
1.000 & 0.080 \\
1.055 & 0.150 \\
1.300 & 0.100 \\
\hline
\end{tabular}

Table 11. Withdrawal Rate Assumptions for Decline in Total Liabilities (percent)

\begin{tabular}{lcc}
\hline Default & \multicolumn{2}{c}{ Withdrawal Rate } \\
\cline { 2 - 3 } Probability & Case 1 & Case 2 \\
\hline & & \\
$10-20$ & 5 & $7-10$ \\
$20-35$ & 10 & $14-21$ \\
$>35$ & 25 & 42 \\
\hline
\end{tabular}

Sources: SNL Financial; and author estimates. 
Figure 3. Capital Ratios, 1987-2006 and 2007-2010; Before Interbank Failures
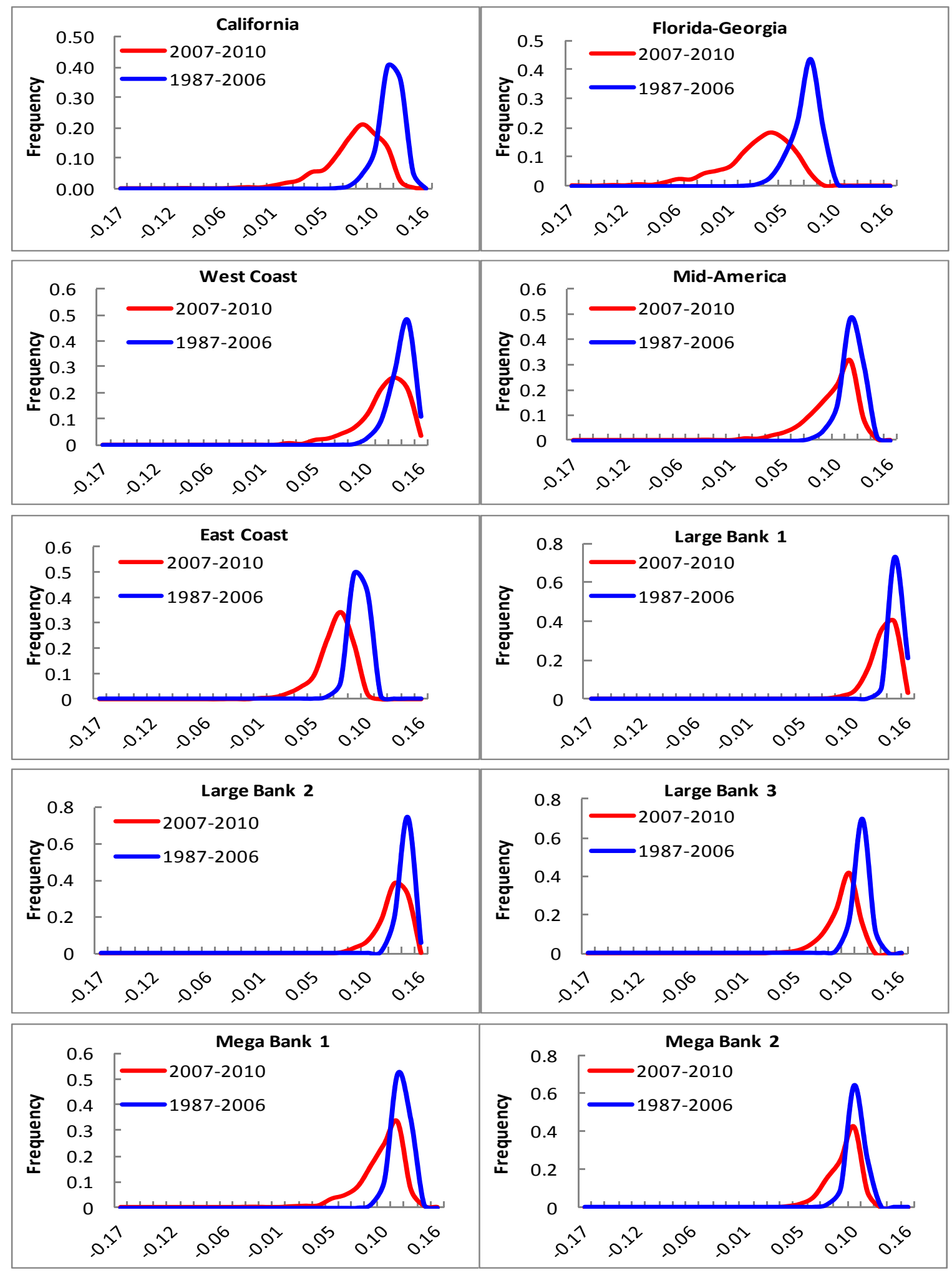

Source: ValueCalc estimates. 
Table 12. Simulated Capital Ratios for Banks using the 1987-2006 Financial Environment with No Inter-Bank Default Losses

\begin{tabular}{|c|c|c|c|c|c|c|c|c|c|c|c|}
\hline & $\begin{array}{c}\text { Capital } \\
\text { Ratio } \\
\text { Bank } 1\end{array}$ & $\begin{array}{c}\text { Capital } \\
\text { Ratio } \\
\text { Bank 2 }\end{array}$ & $\begin{array}{c}\text { Capital } \\
\text { Ratio } \\
\text { Bank 3 }\end{array}$ & $\begin{array}{c}\text { Capital } \\
\text { Ratio } \\
\text { Bank 4 }\end{array}$ & $\begin{array}{c}\text { Capital } \\
\text { Ratio } \\
\text { Bank } 5\end{array}$ & $\begin{array}{c}\text { Capital } \\
\text { Ratio } \\
\text { Bank } 6\end{array}$ & $\begin{array}{c}\text { Capital } \\
\text { Ratio } \\
\text { Bank } 7\end{array}$ & $\begin{array}{c}\text { Capital } \\
\text { Ratio } \\
\text { Bank } 8\end{array}$ & $\begin{array}{c}\text { Capital } \\
\text { Ratio } \\
\text { Bank } 9\end{array}$ & $\begin{array}{l}\text { Capital } \\
\text { Ratio } \\
\text { Bank } 10\end{array}$ & $\begin{array}{l}\text { Number of } \\
\text { Failed } \\
\text { Banks }\end{array}$ \\
\hline Average & 0.112 & 0.062 & 0.130 & 0.110 & 0.086 & 0.139 & 0.134 & 0.108 & 0.112 & 0.097 & 0.010 \\
\hline Std. Dev. & 0.013 & 0.014 & 0.012 & 0.011 & 0.008 & 0.006 & 0.006 & 0.007 & 0.009 & 0.008 & 0.101 \\
\hline Max & 0.141 & 0.093 & 0.155 & 0.136 & 0.106 & 0.154 & 0.149 & 0.127 & 0.133 & 0.118 & 1 \\
\hline Min & 0.056 & -0.005 & 0.072 & 0.061 & 0.050 & 0.110 & 0.103 & 0.075 & 0.074 & 0.066 & 0 \\
\hline \multicolumn{12}{|l|}{ Percentile } \\
\hline 0.25 & 0.106 & 0.055 & 0.124 & 0.105 & 0.082 & 0.136 & 0.130 & 0.104 & 0.107 & 0.093 & 0 \\
\hline 0.10 & 0.094 & 0.042 & 0.113 & 0.095 & 0.076 & 0.132 & 0.126 & 0.099 & 0.101 & 0.088 & 0 \\
\hline 0.09 & 0.093 & 0.041 & 0.111 & 0.094 & 0.075 & 0.131 & 0.126 & 0.098 & 0.100 & 0.087 & 0 \\
\hline 0.08 & 0.091 & 0.040 & 0.110 & 0.092 & 0.075 & 0.131 & 0.125 & 0.098 & 0.099 & 0.087 & 0 \\
\hline 0.07 & 0.090 & 0.038 & 0.109 & 0.090 & 0.074 & 0.130 & 0.125 & 0.097 & 0.098 & 0.086 & 0 \\
\hline 0.06 & 0.088 & 0.036 & 0.107 & 0.089 & 0.073 & 0.129 & 0.125 & 0.096 & 0.096 & 0.085 & 0 \\
\hline 0.05 & 0.086 & 0.035 & 0.105 & 0.088 & 0.072 & 0.128 & 0.123 & 0.096 & 0.094 & 0.085 & 0 \\
\hline 0.04 & 0.084 & 0.033 & 0.103 & 0.086 & 0.069 & 0.128 & 0.122 & 0.095 & 0.093 & 0.083 & 0 \\
\hline 0.03 & 0.082 & 0.030 & 0.101 & 0.084 & 0.068 & 0.126 & 0.121 & 0.093 & 0.092 & 0.081 & 0 \\
\hline 0.02 & 0.079 & 0.026 & 0.098 & 0.080 & 0.065 & 0.124 & 0.119 & 0.091 & 0.089 & 0.078 & 0 \\
\hline 0.01 & 0.073 & 0.020 & 0.093 & 0.075 & 0.062 & 0.121 & 0.117 & 0.088 & 0.086 & 0.074 & 0 \\
\hline 0.001 & 0.057 & 0.004 & 0.076 & 0.068 & 0.053 & 0.114 & 0.108 & 0.077 & 0.075 & 0.066 & 1 \\
\hline
\end{tabular}

Source: ValueCalc Estimates.

Table 13. Simulated Capital Ratios for Banks using the 2007-2010 Financial Environment Calibration with No Inter-Bank Default Losses (percent)

\begin{tabular}{|c|c|c|c|c|c|c|c|c|c|c|c|}
\hline & $\begin{array}{l}\text { Capital } \\
\text { Ratio } \\
\text { Bank } 1\end{array}$ & $\begin{array}{l}\text { Capital } \\
\text { Ratio } \\
\text { Bank } 2\end{array}$ & $\begin{array}{l}\text { Capital } \\
\text { Ratio } \\
\text { Bank } 3\end{array}$ & $\begin{array}{c}\text { Capital } \\
\text { Ratio } \\
\text { Bank } 4\end{array}$ & $\begin{array}{l}\text { Capital } \\
\text { Ratio } \\
\text { Bank } 5\end{array}$ & $\begin{array}{l}\text { Capital } \\
\text { Ratio } \\
\text { Bank } 6\end{array}$ & $\begin{array}{l}\text { Capital } \\
\text { Ratio } \\
\text { Bank } 7\end{array}$ & $\begin{array}{l}\text { Capital } \\
\text { Ratio } \\
\text { Bank } 8\end{array}$ & $\begin{array}{c}\text { Capital } \\
\text { Ratio } \\
\text { Bank } 9\end{array}$ & $\begin{array}{l}\text { Capital } \\
\text { Ratio } \\
\text { Bank } 10\end{array}$ & $\begin{array}{l}\text { Number of } \\
\text { Failed } \\
\text { Banks }\end{array}$ \\
\hline Average & 0.072 & 0.012 & 0.110 & 0.090 & 0.061 & 0.124 & 0.120 & 0.087 & 0.092 & 0.084 & 0.655 \\
\hline Std. Dev. & 0.031 & 0.036 & 0.026 & 0.024 & 0.018 & 0.014 & 0.015 & 0.018 & 0.022 & 0.017 & 0.914 \\
\hline Max & 0.130 & 0.088 & 0.157 & 0.134 & 0.099 & 0.151 & 0.147 & 0.124 & 0.133 & 0.116 & 8 \\
\hline Min & -0.105 & -0.173 & -0.025 & -0.038 & -0.036 & 0.054 & 0.037 & -0.009 & -0.038 & 0.001 & 0 \\
\hline \multicolumn{12}{|l|}{ Percentile } \\
\hline 0.25 & 0.057 & -0.005 & 0.097 & 0.078 & 0.051 & 0.117 & 0.113 & 0.078 & 0.082 & 0.075 & 1 \\
\hline 0.10 & 0.029 & -0.039 & 0.075 & 0.058 & 0.037 & 0.106 & 0.100 & 0.063 & 0.061 & 0.062 & 1 \\
\hline 0.09 & 0.026 & -0.042 & 0.072 & 0.054 & 0.034 & 0.105 & 0.098 & 0.061 & 0.060 & 0.061 & 1 \\
\hline 0.08 & 0.024 & -0.044 & 0.070 & 0.051 & 0.033 & 0.103 & 0.097 & 0.060 & 0.059 & 0.059 & 1 \\
\hline 0.07 & 0.022 & -0.048 & 0.067 & 0.048 & 0.031 & 0.103 & 0.095 & 0.057 & 0.056 & 0.057 & 1 \\
\hline 0.0 & 0.017 & -0.051 & 0.063 & 0.046 & 0.029 & 0.101 & 0.093 & 0.054 & 0.052 & 0.055 & 2 \\
\hline 0.0 & 0.014 & -0.057 & 0.058 & 0.044 & 0.026 & 0.099 & 0.091 & 0.051 & 0.048 & 0.053 & 2 \\
\hline 0.04 & 0.008 & -0.066 & 0.054 & 0.039 & 0.022 & 0.096 & 0.088 & 0.048 & 0.042 & 0.050 & 2 \\
\hline 0.03 & 0.000 & -0.071 & 0.047 & 0.033 & 0.018 & 0.092 & 0.084 & 0.043 & 0.040 & 0.046 & 3 \\
\hline 0.02 & -0.008 & -0.081 & 0.043 & 0.025 & 0.014 & 0.089 & 0.080 & 0.038 & 0.036 & 0.042 & 3 \\
\hline 0.01 & -0.021 & -0.092 & 0.032 & 0.016 & 0.002 & 0.081 & 0.075 & 0.023 & 0.026 & 0.033 & 4 \\
\hline 0.005 & -0.036 & -0.114 & 0.012 & 0.001 & -0.008 & 0.076 & 0.068 & 0.015 & 0.014 & 0.025 & 7 \\
\hline
\end{tabular}

Source: ValueCalc Estimates. 
Table 14. Simulated Capital Ratios for Banks using the 2007-2010 Financial Environment Calibration with First and Second Round of Inter-bank Default Losses (percent)

\begin{tabular}{|c|c|c|c|c|c|c|c|c|c|c|c|}
\hline & $\begin{array}{c}\text { Capital } \\
\text { Ratio } \\
\text { Bank 1 }\end{array}$ & $\begin{array}{c}\text { Capital } \\
\text { Ratio } \\
\text { Bank 2 }\end{array}$ & $\begin{array}{c}\text { Capital } \\
\text { Ratio } \\
\text { Bank } 3\end{array}$ & $\begin{array}{c}\text { Capital } \\
\text { Ratio } \\
\text { Bank } 4\end{array}$ & $\begin{array}{c}\text { Capital } \\
\text { Ratio } \\
\text { Bank 5 }\end{array}$ & $\begin{array}{c}\text { Capital } \\
\text { Ratio } \\
\text { Bank } 6\end{array}$ & $\begin{array}{c}\text { Capital } \\
\text { Ratio } \\
\text { Bank } 7\end{array}$ & $\begin{array}{c}\text { Capital } \\
\text { Ratio } \\
\text { Bank } 8\end{array}$ & $\begin{array}{c}\text { Capital } \\
\text { Ratio } \\
\text { Bank } 9\end{array}$ & $\begin{array}{l}\text { Capital } \\
\text { Ratio } \\
\text { Bank } 10\end{array}$ & $\begin{array}{l}\text { Number of } \\
\text { Failed } \\
\text { Banks }\end{array}$ \\
\hline Average & 0.072 & 0.012 & 0.110 & 0.090 & 0.059 & 0.122 & 0.120 & 0.086 & 0.091 & 0.083 & 1 \\
\hline Std. Dev. & 0.033 & 0.039 & 0.027 & 0.025 & 0.024 & 0.019 & 0.016 & 0.020 & 0.023 & 0.018 & \\
\hline Max & 0.129 & 0.088 & 0.157 & 0.133 & 0.099 & 0.151 & 0.146 & 0.124 & 0.132 & 0.116 & 10 \\
\hline Min & -0.145 & -0.236 & -0.058 & -0.061 & -0.145 & -0.042 & 0.008 & -0.048 & -0.069 & -0.030 & 0 \\
\hline \multicolumn{12}{|l|}{ Percentile } \\
\hline 0.25 & 0.057 & -0.005 & 0.097 & 0.078 & 0.049 & 0.116 & 0.112 & 0.078 & 0.081 & 0.074 & 1 \\
\hline 0.10 & 0.028 & -0.040 & 0.075 & 0.058 & 0.035 & 0.104 & 0.099 & 0.063 & 0.060 & 0.061 & 1 \\
\hline 0.09 & 0.026 & -0.042 & 0.071 & 0.054 & 0.032 & 0.103 & 0.098 & 0.061 & 0.059 & 0.060 & 1 \\
\hline 0.08 & 0.023 & -0.045 & 0.069 & 0.051 & 0.031 & 0.101 & 0.096 & 0.059 & 0.058 & 0.058 & 1 \\
\hline 0.07 & 0.021 & -0.048 & 0.066 & 0.048 & 0.029 & 0.100 & 0.094 & 0.056 & 0.055 & 0.056 & 1 \\
\hline 0.06 & 0.016 & -0.051 & 0.063 & 0.046 & 0.027 & 0.099 & 0.092 & 0.053 & 0.050 & 0.053 & 2 \\
\hline 0.05 & 0.013 & -0.058 & 0.057 & 0.043 & 0.024 & 0.097 & 0.090 & 0.049 & 0.046 & 0.051 & 2 \\
\hline 0.04 & 0.008 & -0.068 & 0.052 & 0.038 & 0.019 & 0.094 & 0.087 & 0.046 & 0.040 & 0.048 & 3 \\
\hline 0.03 & -0.001 & -0.074 & 0.046 & 0.031 & 0.015 & 0.087 & 0.083 & 0.041 & 0.038 & 0.043 & 3 \\
\hline 0.02 & -0.009 & -0.083 & 0.041 & 0.024 & 0.009 & 0.083 & 0.079 & 0.035 & 0.034 & 0.035 & 3 \\
\hline 0.01 & -0.032 & -0.104 & 0.024 & 0.005 & -0.027 & 0.055 & 0.060 & 0.005 & 0.022 & 0.019 & 6 \\
\hline 0.001 & -0.092 & -0.193 & -0.024 & -0.024 & -0.113 & -0.026 & 0.034 & -0.024 & -0.027 & -0.010 & 9 \\
\hline 0.0001 & -0.139 & -0.231 & -0.054 & -0.057 & -0.141 & -0.041 & 0.011 & -0.045 & -0.064 & -0.028 & 10 \\
\hline
\end{tabular}

Source: ValueCalc Estimates. 
Table 15. Correlations among Incremental Bank Failures Due to Inter-Bank Default losses and Initial Bank Failures.

\begin{tabular}{|c|c|c|c|c|c|c|c|c|c|c|c|c|c|}
\hline & $\begin{array}{l}\text { Incremental } \\
\text { Number of } \\
\text { Banks } \\
\text { Failing in } \\
\text { Step 1 }\end{array}$ & $\begin{array}{l}\text { Incremental } \\
\text { Number of } \\
\text { Banks } \\
\text { Failing in } \\
\text { Step 2 } \\
\end{array}$ & $\begin{array}{l}\text { Bank } 1 \\
\text { Failure }\end{array}$ & $\begin{array}{l}\text { Bank } 2 \\
\text { Failure }\end{array}$ & $\begin{array}{l}\text { Bank } 3 \\
\text { Failure }\end{array}$ & $\begin{array}{l}\text { Bank } 4 \\
\text { Failure }\end{array}$ & $\begin{array}{l}\text { Bank } 5 \\
\text { Failure } \\
\end{array}$ & $\begin{array}{l}\text { Bank } 6 \\
\text { Failure }\end{array}$ & $\begin{array}{l}\text { Bank } 7 \\
\text { Failure }\end{array}$ & $\begin{array}{l}\text { Bank } 8 \\
\text { Failure }\end{array}$ & $\begin{array}{l}\text { Bank } 9 \\
\text { Failure }\end{array}$ & $\begin{array}{c}\text { Bank } 10 \\
\text { Failure }\end{array}$ & $\begin{array}{l}\text { Bank } 9 \text { or } \\
10 \text { Failure }\end{array}$ \\
\hline $\begin{array}{l}\text { Incremental Number of } \\
\text { Banks Failing Step } 1 \\
\text { Incremental Number of }\end{array}$ & 1.00 & & & & & & & & & & & & \\
\hline Banks Failing Step 2 & 0.72 & 1.00 & & & & & & & & & & & \\
\hline Bank 1 Failure & 0.45 & 0.33 & 1.00 & & & & & & & & & & \\
\hline Bank 2 Failure & 0.12 & 0.09 & 0.26 & 1.00 & & & & & & & & & \\
\hline Bank 3 Failure & 0.57 & 0.54 & 0.33 & 0.08 & 1.00 & & & & & & & & \\
\hline Bank 4 Failure & 0.56 & 0.60 & 0.45 & 0.12 & 0.73 & 1.00 & & & & & & & \\
\hline Bank 5 Failure & 0.47 & 0.45 & 0.67 & 0.19 & 0.45 & 0.58 & 1.00 & & & & & & \\
\hline Bank 6 Failure & n.a. & n.a. & n.a. & n.a. & n.a. & n.a. & n.a. & 1.00 & & & & & \\
\hline Bank 7 Failure & n.a. & n.a. & n.a. & n.a. & n.a. & n.a. & n.a. & n.a. & 1.00 & & & & \\
\hline Bank 8 Failure & 0.41 & 0.54 & 0.33 & 0.08 & 0.75 & 0.73 & 0.45 & n.a. & n.a. & 1.00 & & & \\
\hline Bank 9 Failure & 0.73 & 0.69 & 0.35 & 0.09 & 0.82 & 0.69 & 0.48 & n.a. & n.a. & 0.70 & 1.00 & & \\
\hline Bank 10 Failure & 0.42 & 0.15 & 0.20 & 0.05 & 0.61 & 0.44 & 0.28 & n.a. & n.a. & 0.41 & 0.38 & 1.00 & \\
\hline
\end{tabular}

Source: ValueCalc Estimates 
Table 16. Distributional Analysis of Bank Probabilities of Default at T2 as Measured at T1

\begin{tabular}{|c|c|c|c|c|c|c|c|c|c|c|c|}
\hline & Bank 1 & Bank 2 & Bank 3 & Bank 4 & Bank 5 & Bank 6 & Bank 7 & Bank 8 & Bank 9 & Bank 10 & $\begin{array}{l}\text { Wtd Avg } \\
\text { for } \\
\text { Banking } \\
\text { System }\end{array}$ \\
\hline Average & 0.287 & 0.866 & 0.042 & 0.073 & 0.202 & 0.020 & 0.003 & 0.039 & 0.047 & 0.030 & 0.091 \\
\hline Std. Dev. & 0.270 & 0.177 & 0.113 & 0.147 & 0.236 & 0.100 & 0.034 & 0.116 & 0.116 & 0.107 & 0.106 \\
\hline Max & 1 & 1 & 1 & 1 & 1 & 1 & 1 & 1 & 1 & 1 & 1 \\
\hline $\begin{array}{l}\text { Min } \\
\text { Percentile }\end{array}$ & 0.024 & 0.213 & 0.006 & 0.007 & 0.012 & 0.009 & 0.000 & 0.009 & 0.007 & 0.003 & 0.016 \\
\hline 0.99 & 1.000 & 1.000 & 0.706 & 1.000 & 1.000 & 0.430 & 0.041 & 1.000 & 0.693 & 0.681 & 0.633 \\
\hline 0.95 & 1.000 & 1.000 & 0.162 & 0.282 & 0.799 & 0.010 & 0.009 & 0.124 & 0.195 & 0.075 & 0.227 \\
\hline 0.90 & 0.754 & 1.000 & 0.083 & 0.151 & 0.510 & 0.010 & 0.005 & 0.058 & 0.103 & 0.035 & 0.154 \\
\hline 0.75 & 0.366 & 1.000 & 0.032 & 0.061 & 0.264 & 0.009 & 0.000 & 0.022 & 0.037 & 0.018 & 0.093 \\
\hline 0.50 & 0.176 & 1.000 & 0.010 & 0.027 & 0.102 & 0.009 & 0.000 & 0.011 & 0.010 & 0.010 & 0.065 \\
\hline 0.25 & 0.100 & 0.769 & 0.009 & 0.012 & 0.058 & 0.009 & 0.000 & 0.010 & 0.009 & 0.007 & 0.050 \\
\hline 0.10 & 0.062 & 0.575 & 0.009 & 0.010 & 0.037 & 0.009 & 0.000 & 0.010 & 0.009 & 0.006 & 0.038 \\
\hline 0.09 & 0.058 & 0.552 & 0.009 & 0.010 & 0.036 & 0.009 & 0.000 & 0.010 & 0.009 & 0.006 & 0.037 \\
\hline 0.08 & 0.057 & 0.538 & 0.009 & 0.010 & 0.036 & 0.009 & 0.000 & 0.010 & 0.009 & 0.005 & 0.036 \\
\hline 0.07 & 0.054 & 0.520 & 0.009 & 0.010 & 0.034 & 0.009 & 0.000 & 0.010 & 0.009 & 0.005 & 0.034 \\
\hline 0.06 & 0.053 & 0.501 & 0.008 & 0.010 & 0.034 & 0.009 & 0.000 & 0.010 & 0.009 & 0.005 & 0.033 \\
\hline 0.05 & 0.045 & 0.491 & 0.008 & 0.010 & 0.032 & 0.009 & 0.000 & 0.010 & 0.009 & 0.005 & 0.032 \\
\hline 0.04 & 0.044 & 0.471 & 0.008 & 0.009 & 0.030 & 0.009 & 0.000 & 0.010 & 0.009 & 0.005 & 0.032 \\
\hline 0.03 & 0.040 & 0.458 & 0.008 & 0.009 & 0.024 & 0.009 & 0.000 & 0.010 & 0.009 & 0.004 & 0.031 \\
\hline 0.02 & 0.038 & 0.420 & 0.007 & 0.009 & 0.021 & 0.009 & 0.000 & 0.010 & 0.009 & 0.004 & 0.029 \\
\hline 0.01 & 0.033 & 0.368 & 0.007 & 0.008 & 0.020 & 0.009 & 0.000 & 0.010 & 0.008 & 0.004 & 0.025 \\
\hline 0.001 & 0.024 & 0.287 & 0.006 & 0.008 & 0.012 & 0.009 & 0.000 & 0.009 & 0.007 & 0.004 & 0.021 \\
\hline
\end{tabular}

Source: ValueCalc Estimates 
Table 17. Simulated Distribution of Total Solvency plus Liquidity Induced Bank Failures

\begin{tabular}{lrr}
\hline & \multicolumn{2}{c}{ Max Liquidity } \\
& Run $=25 \%$ & \multicolumn{2}{c}{ Run Liquidity $=42 \%$} \\
& Total Assets & \multicolumn{1}{c}{ Total Assets } \\
\hline Average & 1.33 & 1.43 \\
Std. Dev. & 1.03 & 1.19 \\
Max & 10.00 & 10.00 \\
Min & 0.00 & 0.00 \\
Percentile & & \\
0.99 & 0.00 & 0.00 \\
0.95 & 1.00 & 1.00 \\
0.90 & 1.00 & 1.00 \\
0.75 & 1.00 & 1.00 \\
0.50 & 1.00 & 1.00 \\
0.25 & 1.00 & 1.00 \\
0.10 & 2.00 & 3.00 \\
0.09 & 2.00 & 3.00 \\
0.08 & 2.00 & 3.00 \\
0.07 & 2.00 & 3.00 \\
0.06 & 2.00 & 3.00 \\
0.05 & 2.05 & 3.00 \\
0.04 & 3.00 & 3.00 \\
0.03 & 4.00 & 4.00 \\
0.02 & 4.00 & 4.00 \\
0.01 & 7.00 & 8.00 \\
0.001 & 9.00 & 10.00 \\
\hline Source: ValueCalc Estimates &
\end{tabular}


Figure 4. Net Cash Flows (after asset fire sales), 2007-2010 (percent of total assets)



Source: ValueCalc Estimates. 
Table 18. Probability of Banks Having Liquidity Shortage (Negative Net Cash Flow), 2007-2010.

\begin{tabular}{rr}
\hline $\begin{array}{c}\text { Number of } \\
\text { Banks }\end{array}$ & Probability \\
\hline 0 & 1.51 \\
1 & 75.38 \\
2 & 17.17 \\
3 & 2.36 \\
4 & 1.89 \\
5 & 0.57 \\
6 & 0.09 \\
7 & 0.00 \\
8 & 0.09 \\
9 & 0.85 \\
10 & 0.09 \\
\hline Source: ValueCalc estimates
\end{tabular}

Figure 5. Total Loan Reductions.

(percent of total loans)

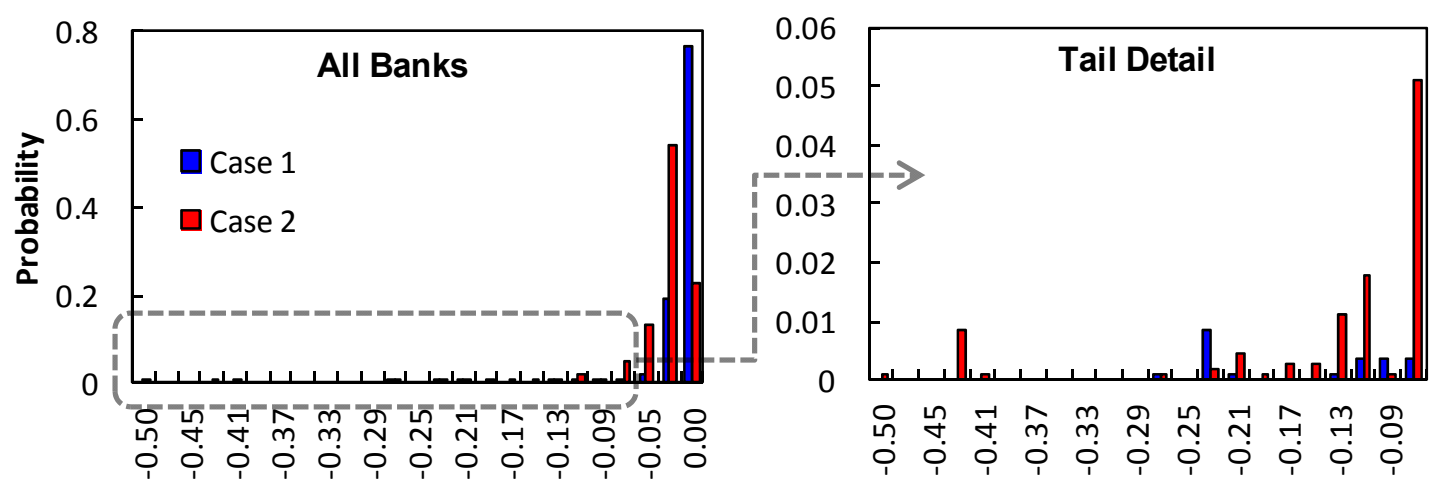

Sources: SNL Financial; and IMF staff estimates.

Notes: The right panel shows the results of the left panel with a finer set of $x$-axis losses of loans and lower probability (y-axis). 
Table 19. Simulated Percentage Reduction in Bank Loans after Liquidity Shock (Case 1 for BHC's)

\begin{tabular}{|c|c|c|c|c|c|c|c|c|c|c|c|}
\hline & Bank 1 & Bank 2 & Bank 3 & Bank 4 & Bank 5 & Bank 6 & Bank 7 & Bank 8 & Bank 9 & Bank 10 & $\begin{array}{c}\text { Total } \\
\text { Banking } \\
\text { System }\end{array}$ \\
\hline Average & -12.05 & -25.99 & -1.03 & -2.20 & -8.43 & -0.50 & -0.18 & -0.99 & -0.83 & -0.31 & -2.84 \\
\hline Std. Dev. & 10.49 & 1.63 & 4.21 & 5.85 & 10.54 & 4.86 & 1.86 & 4.30 & 3.46 & 2.15 & 2.94 \\
\hline Max & 0.00 & -19.08 & 0.00 & 0.00 & 0.00 & 0.00 & 0.00 & 0.00 & 0.00 & 0.00 & -1.08 \\
\hline Min & -33.58 & -37.63 & -28.17 & -26.74 & -41.04 & -50.57 & -32.92 & -29.76 & -24.52 & -19.06 & -27.19 \\
\hline \multicolumn{12}{|l|}{ Percentile } \\
\hline 0.99 & 0.00 & -19.69 & 0.00 & 0.00 & 0.00 & 0.00 & 0.00 & 0.00 & 0.00 & 0.00 & -1.10 \\
\hline 0.95 & 0.00 & -24.44 & 0.00 & 0.00 & 0.00 & 0.00 & 0.00 & 0.00 & 0.00 & 0.00 & -1.36 \\
\hline 0.90 & 0.00 & -24.71 & 0.00 & 0.00 & 0.00 & 0.00 & 0.00 & 0.00 & 0.00 & 0.00 & -1.37 \\
\hline 0.75 & -4.21 & -25.15 & 0.00 & 0.00 & 0.00 & 0.00 & 0.00 & 0.00 & 0.00 & 0.00 & -1.60 \\
\hline 0.50 & -4.38 & -25.81 & 0.00 & 0.00 & -4.97 & 0.00 & 0.00 & 0.00 & 0.00 & 0.00 & -1.80 \\
\hline 0.25 & -19.82 & -26.57 & 0.00 & 0.00 & -21.18 & 0.00 & 0.00 & 0.00 & 0.00 & 0.00 & -3.06 \\
\hline 0.10 & -25.64 & -27.60 & 0.00 & -3.82 & -25.44 & 0.00 & 0.00 & 0.00 & -0.80 & 0.00 & -3.97 \\
\hline 0.09 & -25.76 & -27.70 & -2.70 & -13.25 & -25.55 & 0.00 & 0.00 & 0.00 & -0.80 & 0.00 & -4.29 \\
\hline 0.08 & -25.79 & -27.77 & -2.72 & -17.56 & -25.69 & 0.00 & 0.00 & 0.00 & -0.81 & 0.00 & -4.47 \\
\hline 0.07 & -25.90 & -27.86 & -2.73 & -17.64 & -25.80 & 0.00 & 0.00 & 0.00 & -0.93 & 0.00 & -4.61 \\
\hline 0.06 & -26.02 & -28.07 & -2.80 & -17.71 & -25.88 & 0.00 & 0.00 & -6.21 & -0.95 & 0.00 & -5.00 \\
\hline 0.05 & -26.07 & -28.33 & -2.86 & -17.86 & -26.00 & 0.00 & 0.00 & -6.40 & -11.41 & 0.00 & -8.18 \\
\hline 0.04 & -26.34 & -28.59 & -17.55 & -18.04 & -26.17 & 0.00 & 0.00 & -6.52 & -11.60 & 0.00 & -8.85 \\
\hline 0.03 & -26.46 & -28.78 & -17.67 & -22.50 & -26.46 & 0.00 & 0.00 & -19.02 & -11.68 & 0.00 & -10.04 \\
\hline 0.02 & -26.85 & -29.13 & -17.80 & -22.69 & -26.60 & 0.00 & 0.00 & -19.60 & -11.78 & -6.28 & -11.98 \\
\hline 0.01 & -28.24 & -30.66 & -23.79 & -23.51 & -29.39 & -16.58 & -4.82 & -25.30 & -20.10 & -16.16 & -18.02 \\
\hline 0.001 & -31.80 & -36.10 & -27.07 & -25.65 & -39.58 & -48.82 & -20.06 & -28.99 & -23.44 & -18.47 & -25.07 \\
\hline
\end{tabular}

Source: ValueCalc Estimates. 
Table 20. Additional equity capital required at T0 for banks to have a 99 percent confidence level that at $\mathrm{T} 1$ they would less than a 10 percent probability of failing by $\mathrm{T} 2$

\begin{tabular}{lccccccccrr}
\hline & $\begin{array}{c}\text { Capital } \\
\text { Ratio } \\
\text { Bank 1 }\end{array}$ & $\begin{array}{c}\text { Capital } \\
\text { Ratio } \\
\text { Bank 2 }\end{array}$ & $\begin{array}{c}\text { Capital } \\
\text { Ratio } \\
\text { Bank 3 }\end{array}$ & $\begin{array}{c}\text { Capital } \\
\text { Ratio } \\
\text { Bank 4 }\end{array}$ & $\begin{array}{c}\text { Capital } \\
\text { Ratio } \\
\text { Bank 5 }\end{array}$ & $\begin{array}{c}\text { Capital } \\
\text { Ratio } \\
\text { Bank 6 }\end{array}$ & $\begin{array}{c}\text { Capital } \\
\text { Ratio } \\
\text { Bank 7 }\end{array}$ & $\begin{array}{c}\text { Capital } \\
\text { Ratio } \\
\text { Bank 8 }\end{array}$ & $\begin{array}{c}\text { Capital } \\
\text { Ratio } \\
\text { Bank 9 } 9\end{array}$ & $\begin{array}{c}\text { Capital } \\
\text { Ratio } \\
\text { Bank 10 }\end{array}$ \\
\hline $\begin{array}{l}\text { Initial Capital Ratios } \\
\begin{array}{l}\text { Approximate Additional Equity } \\
\text { Capital Required at T=0 to Have }\end{array}\end{array}$ & 0.104 & 0.057 & 0.124 & 0.104 & 0.080 & 0.134 & 0.124 & 0.095 & 0.101 & 0.088 \\
$\begin{array}{l}1 \% \text { Pprobability of a 10\% } \\
\text { Probability of Failure at T=1 }\end{array}$ & 0.111 & 0.216 & 0.045 & 0.056 & 0.123 & 0.031 & -0.011 & 0.049 & 0.046 & 0.026 \\
\hline
\end{tabular}

Source: ValueCalc Estimates. 


\section{References}

Acharya, Viral V., Joao A. C. Santos, and Tanju Yorulmazer, 2010, "Systemic Risk and Deposit Insurance Premiums," Economic Policy Review (New York: Federal Reserve Bank of New York, August).

Afonso, Gara, Anna Kovner, and Antoinette Shoar, 2010, "Stressed, Not Frozen: The Federal Funds Market in the Financial Crisis," Federal Reserve Bank of New York Staff Reports No. 437 (March).

Aikmen, David, Alessandro Piergiorgio, Bruno Eklund, Prasanna Gai, Sujit Kapadia, Elizabeth Martin, Nada Mora, Gabriel Sterne, and Matthew Willison, 2009, "Funding Liquidity Risk in a Quantitative Model of Systemic Stability," Bank of England Working Paper No. 372 (June).

Allen, Franklin and Douglas Gale, 2000. "Financial Contagion", Journal of Political Economy, Vol. 108, No.1 (February), pp.1-33.

Barnhill, Theodore, and W. Maxwell, 2002, "Modeling Correlated Interest Rate, Exchange Rate, and Credit Risk in Fixed Income Portfolios," Journal of Banking and Finance, Vol. 26, No. 2-3, pp. 347-74.

Barnhill, Theodore, and M. Souto, 2009 "Systemic Bank Risk in Brazil: A Comprehensive Simulation of Correlated Market, Credit, Sovereign and Inter-Bank Risks", Journal of Financial Markets, Institutions \& Instruments, Volume 18, Issue 4, (November) pp. 243-283.

Barnhill, Theodore, P. Papapanagiotou, and Liliana Schumacher, 2002, "Measuring Integrated Market and Credit Risk in Bank Portfolios: An Application to a Set of Hypothetical Banks Operating in South Africa," Financial Markets, Institutions and Instruments, Vol. 11, No. 5 (December).

Barnhill, Theodore, and Liliana Schumacher, forthcoming, "Modeling Correlated Systemic Liquidity and Solvency Risks in a Volatile Environment with Incomplete Information," IMF Working Paper (Washington: International Monetary Fund).

Basel Committee on Banking Supervision, 2009, "Revisions to the Basel II Market Risk Framework" (Basel: Bank for International Settlements, July).

, 2010a, "Basel III: International Framework for Liquidity Risk Measurement, Standards and Monitoring” (Basel: Bank for International Settlements, December). , 2010b, "Results of the Comprehensive Quantitative Impact Study" (Basel: Bank for International Settlements, December). 
Bhutta, Neil, Jane Dokko, and Hui Shan, "Consumer Ruthlessness and Strategic Default During the 2007-2009 Housing Bust", Federal Reserve Board of Governors, July 2010.

Black, Fischer, and Myron Scholes, 1973, "The Pricing of Options and Corporate Liabilities," Journal of Political Economy, Vol. 81, No. 3, pp. 637-54.

Brunnermeier, Markus, Andrew Crocket, Charles Goodhart, Martin Hellwig, Avi Persaud, and Hyun Song Shin, 2009, "The Fundamental Principles of Financial Regulation" Geneva Reports on the World Economy 11.

Brunnermeier, Markus, and Lasse Pedersen, 2009, "Market Liquidity and Funding Liquidity," Review of Financial Studies, Vol. 22, No. 6, pp. 2201-38.

Cantor, Richard Martin and Varma, Praveen, 2004, "Determinants of Recovery Rates on Defaulted Bonds and Loans for North American Corporate Issuers: 1983-2003." Journal of Fixed Income (December).

Coval, Joshua, and Erik Stafford, 2007, "Asset Fire Sales (and Purchases) in Equity Markets,” Journal of Financial Economics, Vol. 86, pp. 479-512.

Diamond, Douglas, and Philip Dybvig, 1983, "Bank Runs, Deposit Insurance, and Liquidity.” Journal of Political Economy, Vol. 91, No.3, pp. 401-19 (June).

Duffie, Darrell, Nicolae Gârleanu, and Lasse Pedersen, 2006, "Valuation in Over-theCounter Markets," NBER Working Paper No. 12020 (February).

Farhi, Emmanuel, Mikhail Golosov, and Aleh Tsyvinski, 2009, "A Theory of Liquidity and Regulation of Financial Intermediation," Review of Economic Studies, Vol. 76, No. 3 , pp. 973-92.

Financial Times, 2008, “Wholesale Jitters Take Toll on HBOS," September 16.

Gorton, Gary, 1988, "Banking Panics and Business Cycles". Oxford Economic Papers, New Series, Vol. 40, No. 4 (December), pp. 751-781.

and Andrew Metrick, 2009, "Securitized Banking and the Run on the Repo," NBER Working Paper No. 15223 (August).

International Monetary Fund (IMF), 2008, Global Financial Stability Report, World Economic and Financial Surveys (Washington: International Monetary Fund, October). 
, 2010, Global Financial Stability Report, World Economic and Financial Surveys (Washington: International Monetary Fund, October).

, and Financial Stability Board (IMF/FSB), 2009, "The Financial Crisis and Information Gaps," Report to the G-20 Finance Ministers and Central Bank Governors (October). , and Financial Stability Board (IMF/IMF), 2010, "The Financial Crisis and Information Gaps,” Progress Report, action Plans and Time Tables (May).

J.P. Morgan, CreditMetrics, 1997.

Merton, Robert, 1973, “Theory of Rational Option Pricing," Bell Journal of Economics and Management Science, Vol. 4 (Spring), pp. 141-83.

Shin, Hyun Song, 2009, "Reflections on Modern Bank Runs: A Case Study of Northern Rock," Journal of Economic Perspectives, Vol. 23, No. 1, pp.101-19.

Shleifer, Andrei, and Robert Vishny, 2010, "Fire Sales in Finance and Macroeconomics," NBER Working Paper - 16642.

Taylor, John B., 2008, “The Financial Crisis and The Policy Respones: An Empirical Analysis of What Went Wrong." Bank of Canada. A Festschrift in Honour of David Doge. Keynote Speech. (November).

van den End, Jan Willem, 2008, "Liquidity Stress-Tester: A Macro model for Stress-testing Banks’ Liquidity Risk,” Dutch National Bank Working Paper No. 175 (May).

Varma, Praveen, and Richard Cantor, 2005, "Determinants of Recovery Rates on Defaulted Bonds and Loans for North American Corporate Issuers: 1983-2003,"Journal of Fixed Income, Vol. 14, No. 4 (March), pp. 29-44.

Wong, Eric, and Cho-Hoi Hui, 2009, “A Liquidity Risk Stress-Testing Framework with Interaction between Market and Credit Risks," Hong Kong Monetary Authority Working Paper 06/2009. 